\title{
Türkiye'deki Boylu Ardıç (Juniperus excelsa M. Bieb) Popülasyonlarının Yayılış Gösterdiği Toprakların Bazı Fiziksel ve Kimyasal Özellikler Bakımından Karşılaştırılması
}

\section{A Comparison of Some Physical and Chemical Soil Characteristics of Crimean Juniper (Juniperus excelsa M. Bieb) Populations in Turkey}

\section{Özay Hasan EVREN ${ }^{1}$, Nuray KAYA ${ }^{2}$}

\section{Öz}

Boylu/Boz Ardıç (Juniperus excelsa M. Bieb.) Türkiye'deki ardıç ormanlarının \%82'lik kısmını oluşturmaktadır. Türkiye'deki ardıç ormanları içinde bu baskın türün yetiştiği toprak koşullarını araştırmak amacıyla coğrafik özellikleri bakımından farklı 20 popülasyondan toprak örnekleri alınmıştır. Toprak örnekleri bünye, $\mathrm{pH}$, tuzluluk, kireç, organik madde ve bazı mutlak besin elementleri miktarı bakımından analiz edilmiştir. Yapılan analizler sonucunda toprak bünyelerinin tınlı veya kumlu tın olduğu, $\mathrm{pH}$ değerlerinin 7,0-8,0 aralığında olduğu ve toprakların genellikle tuzsuz olduğu görülmüştür. Örneklerin çoğunda kireç ve organik madde miktarları orta veya yüksek düzeylerde bulunmuştur. Ca ve Fe miktarları fazla, P miktarı orta-yüksek, Cu miktarı yeterlidir. Ancak K, $\mathrm{Mg}, \mathrm{Zn}$ ve Mn miktarları ise oldukça değişkendir. Hem bu çalışmanın hem de benzer diğer çalışmaların bulguları karşılaş̧ırmalı olarak incelendiğinde, boylu ardıcın yetişmek için ihtiyaç duyduğu toprak koşullarının oldukça esnek olduğu sonucuna ulaşılmıştır. Bunun yanında, bu türün zorlu toprak koşullarına uyum sağlayarak yetişebildiği ve ormanlar oluşturabildiği görülmüştür. Elde edilen sonuçlar da bu türün ekolojik önemini ortaya koymaktadır.

Anahtar Kelimeler: Boylu Ardıç, ekolojik önem, esneklik, Juniperus excelsa, toprak özellikleri

\begin{abstract}
Crimean Juniper (Juniperus excelsa M. Bieb.) covers almost $82 \%$ of juniper forests in Turkey. To investigate the soil conditions where this species grows, the soil samples were taken from 20 geographically different populations. The soil samples were analyzed with respect to texture, $\mathrm{pH}$, salinity, lime, organic matter and some nutrients which are important for plant growth. As a results; the soil textures were loamy and sandy loam. It was seen that $\mathrm{pH}$ values ranged from 7.0 to 8.0 and there was generally no salinity in the soil samples. The amounts of lime and organic matter were moderate to high in the majority of soil specimens. The amounts of $\mathrm{Ca}$ and Fe were high while the amount of $\mathrm{P}$ was moderate to high. However, the amounts of $\mathrm{K}, \mathrm{Mg}, \mathrm{Zn}$ and $\mathrm{Mn}$ were highly variable. When it was compared our study results and other similar research, we concluded that soil conditions of Crimean Juniper needed for grow were pretty flexible. Besides, it was seen that the individuals of this species were be able to grow by adapting to challenging soil conditions, and so they could form forests. All these conclusions reveal ecological importance of this species.
\end{abstract}

Keywords: Crimean Juniper, ecological importance, tolerance, Juniperus excelsa, soil proporties.

\footnotetext{
1*Sorumlu Yazar/Corresponding Author: Özay Hasan Evren, Akdeniz Üniversitesi, Fen Fakültesi, Biyoloji Bölümü, Antalya E-mail: ozayevren86@ gmail.com (iD) OrcID: 0000-0003-1932-2125

${ }^{1}$ Nuray Kaya, Akdeniz Üniversitesi, Fen Fakültesi, Biyoloji Bölümü, Antalya. E-mail: nkaya@akdeniz.edu.tr ${ }^{\text {(D) }}$ OrcID: 0000-0002-3227-6680

Atıf/Citation: Evren, Ö, H, Kaya, N. Türkiye' deki boylu ardıç (Juniperus excelsa M. Bieb) popülasyonlarının yayılış gösterdiği toprakların bazı fiziksel ve kimyasal özellikler bakımından karşılaştırılması Tekirdă̆ Ziraat Fakültesi Dergisi, 16(3), xx-xx.

*Bu çalışma Doktora tezinden hazırlanmıştır. Bu çalışma Akd. Ü. BAP tarafından FDK-15-781 numaralı proje ile desteklenmiştir.

CBu çalışma Tekirdağ Namık Kemal Üniversitesi tarafindan Creative Commons Lisansı (https://creativecommons.org/licenses/by-nc/4.0/)

kapsamında yayınlanmıştır. Tekirdağ 2019
} 


\section{Extendend Summary}

Pure and mixed juniper forests are $4.29 \%$ of forest presence in Turkey and Crimean juniper (Juniperus excelsa M. Bieb.) is covers almost $82 \%$ of juniper forests in Turkey (OGM, 2014). J. excelsa naturally also grows in Balkan Peninsula, Crimea, Cyprus, Syrian and Lebanese Mountains (Douaihy et al., 2011). To be able to realize optimum soil conditions is essential in order that forest protection and reforestation purposes. That's why, investigated soil characteristics of forest trees is an important research area. There are two studies on researching soil properties of Crimean juniper forests in Turkey (Gülser et al., 2012; Şenol et al., 2018). However; they were on two restricted regions of Turkey (Lake District and Van-Gevaş). To investigate and obtain more generalizing information of the soil characteristics of Crimean Juniper populations grows in Turkey, the soil samples were taken from 20 geographically different populations which are mentioned in Coode and Cullen (1982) and OGM (2017b). Data about latitude, longitude, altitude, aspect, slope and lay of 20 populations were also recorded. All populations were demonstrated on a map by using information about latitudes and longitudes. After drying, grounding and sifting process, the soil samples were analyzed with respect to texture, lime, acidity $(\mathrm{pH})$, electrical conductivity (salinity), organic matter and some nutrients (phosphorous, potassium, magnesium, calcium, iron, manganese, zinc and copper) which are important for plant growth. After that, the soils samples were classified with respect to texture, lime, $\mathrm{pH}$, salinity, organic matter and the nutrients and statistically evaluated according to parameters of range, average with standard error, skewness and kurtosis. According to the results of analyses, percentages of sand, silt and clay were between $35-76,12-50$ and 5.6-25 respectively. The soil textures were sandy clay loam (1 samples), loamy ( 8 samples) and sandy loam (11 samples). It was seen that $\mathrm{pH}$ values ranged from 7.0 to 8.0 and soils were slightly-moderate alkaline. There was generally no salinity $\left(\mathrm{EC}<2 \mathrm{mS} \mathrm{cm}{ }^{-1}\right.$ ) except two populations (AnkaraBeypazarı and Karabük-Eskipazar) in the soil samples. The amounts of lime (\%0.5-60.8) and organic matter (\%0.5-10.2) were moderate to high in the majority of soil specimens. The amounts of Ca $\left(1.326-15.594 \mathrm{mg} \mathrm{kg}^{-}\right.$ $\left.{ }^{1}\right)$ and $\mathrm{Fe}\left(3.4-27.3 \mathrm{mg} \mathrm{kg}^{-1}\right)$ were high while the amount of $\mathrm{P}\left(6-76 \mathrm{mg} \mathrm{kg}^{-1}\right)$ was moderate to high. However, the amounts of $\mathrm{Mg}\left(35-1039 \mathrm{mg} \mathrm{kg}^{-1}\right), \mathrm{K}\left(12-567 \mathrm{mg} \mathrm{kg}^{-1}\right), \mathrm{Mn}\left(3.4-22.8 \mathrm{mg} \mathrm{kg}^{-1}\right)$ and $\mathrm{Zn}\left(0.1-4.2 \mathrm{mg} \mathrm{kg}^{-1}\right)$ were highly variable. Copper amounts of soils were sufficient $\left(>0.2 \mathrm{mg} \mathrm{kg}^{-1}\right)$. Assessed amounts of $\mathrm{K}, \mathrm{Mg}, \mathrm{Mn}$ and $\mathrm{Zn}$, many of soil samples were insufficient and this situation has potential of deficiency of these four nutrients in such soils. It was found that acidity is negatively correlated with organic matter, salinity and amounts of $\mathrm{P}, \mathrm{K}, \mathrm{Ca}, \mathrm{Fe}, \mathrm{Mn}, \mathrm{Zn}$ and $\mathrm{Cu}(\mathrm{p}<0.05)$. Additionally, organic matter is positively correlated with amounts of $\mathrm{P}, \mathrm{K}, \mathrm{Fe}, \mathrm{Mn}$ and $\mathrm{Zn}$ in soil samples $(\mathrm{p}<0.05)$. It was seen that Crimean Juniper populations weren't any heavy metal stress $(\mathrm{Zn}$ and $\mathrm{Cu})$, because $\mathrm{Zn}$ and $\mathrm{Cu}$ amounts were lower than upper limit in legislation (ÇŞB, 2017). Results of this study were similar to Crimean Juniper populations from Iran and Pakistan with respect to parameter of $\mathrm{pH}$, salinity, texture, lime and organic matter (Sarangzai et al., 2012; Zangiabadi et al., 2012). Although findings of this study, Gülser et al. (2012) and Şenol et el. (2018) from Turkey on Crimean Juniper were resembling pattern, some differences were also found such as texture of soils. As a conclusion, when we compared our results to other similar research, we concluded that soil conditions of Crimean juniper needed for grow were pretty flexible. Besides, it was seen that the individuals of this species were be able to grow by adapting to challenging soil conditions, so they could form forests. All these conclusions once again revealed ecological importance of this species. 
Dünya Bankası'nın 2015 verilerine göre, kendilerine has ekolojik özellikleriyle bir ekosistem özelliğinde olan ormanlar tüm dünya yüzeyinde yaklaşı olarak 40 milyon $\mathrm{km}^{2}$ 'lik bir yüz ölçüme sahiptir. Bu da ormanların dünya karasal alanlarının \%31'ine denk gelmektedir (The World Bank, 2015). Orman Genel Müdürlüğ̈̈’nün 2015 yılı verileri göz önüne alındığında, Türkiye'de ormanların kapladığı alan 22.342.935 hektar olup; bu alan ülke yüzölçümünün \%28,6'lık bir kısmını oluşturmaktadır (OGM, 2017a). Aynı kaynağa göre, Türkiye genelinde bulunan orman varlığının onda dokuzluk bir bölümünü oluşturan (\%90) altı adet ağaç cins ve türünün yüzdeleri sırasıyla; \%26,34 ile meşe (Quercus L. sp.), \%25,11 ile kızılçam (Pinus brutia Ten.), \%19 ile karaçam (Pinus nigra J. F. Arnold), \%8,5 ile kayın (Fagus orientalis Lipsky) \%6,8 ile sarıçam (Pinus sylvestris $\mathrm{L}$.) ve son olarak \%4,29 ile ardıçtır (Juniperus L. sp.). Bu altı cins ağacın yanı sıra; kestane, fıstıkçamı, kavak, köknar, kızılağaç, ladin, ıhlamur, sedir, gürgen, dişbudak ve sıtma ağacı (okaliptüs) gibi türler de Türkiye ormanlarında bulunan önemli ağaçlardır (OGM, 2017a). Buna göre ardıç türleri orman oluşturan ağaç türleri arasında altıncı sırada gelmektedir. 2014 yılında, Orman Genel Müdürlüğü tarafindan yayımlanmış olan "Ardıç Ormanlarının Rehabilitasyonu Eylem Planı (2006-2015)" başlıklı kaynağa göre ise Türkiye genelinde ardıç ormanlarının kapladığı alan 1.113.085 hektar kadardır (OGM, 2014).

Ardiç (Juniperus sp.), Servigiller (Cupressaceae) familyası içerisinde yer alan tek veya iki evcikli, etli kozalaklara sahip, herdem yeşil çalı ve ağaç türlerini barındıran bir cinstir (Adams, 2014). Türkiye'de yayılış gösteren ardıç tür ve alttürleri; andız (J. drupacea Labill), adi/cüce ardıç (J. communis L. subsp. hemisphaerica (J. \& C. Presl) Nyman ve subsp. nana (Willd.) Syme in Sowerby), katran/diken ardıcı (J. oxycedrus L. subsp. oxycedrus Clinton-Baker ve subsp. macrocarpa (Sibth. \& Sm.) Ball., J. oblanga M. Bieb., sabin/kara ardıcı (J. sabina L.), Finike/servi ardıcı (J. phoenicea L.), kokulu/yağ ardıc (J. foetidissima Willd.), boylu/boz ardıç ( $J$. excelsa subsp. excelsa M. Bieb) ve daltaban ardıcı (J. excelsa subsp. polycarpos K. Koch) şeklindedir (Coode ve Cullen, 1982; Güner ve ark., 2012). Türkiye'de ardıç türlerinin oluşturdukları ormanlar içinde en baskın türün \%82 yayılış oranıyla $J$. excelsa M. Bieb. olduğu bildirilmiştir (OGM, 2014). Bu türün bireylerine, bunların oluşturdukları popülasyonlara (ormanlara) deniz etkisinin azaldığı ve bittiği alanlar ile genellikle Güneydoğu Anadolu Bölgesi dışındaki bölgelerde sıklıkla rastlanmakta olup boylu ardıç türü, saf veya diğer ağaç türleriyle (kızılçam, karaçam, sedir vb.) karışık ormanlar oluşturmaktadır.

Boylu ardıç (J. excelsa subsp. excelsa) 35 metre boya ve bir metre gövde çapına ulaşabilen piramidal tepe yapısına sahip bir türdür (OGM, 2014). Ayrıca, bu tür dünya üzerinde Kırım, Balkan Yarımadası ülkeleri (Makedonya, Arnavutluk, Yunanistan), Lübnan ve Güney Kıbrıs'ın dağlık kesimleri ile Türkiye'de yayılış göstermektedir (Douaihy ve ark., 2011; Foatidis ve ark., 2012). Ancak; Douaihy ve ark. (2011), Foatidis ve ark. (2012) ve OGM (2014) verileri göz önüne alındığında sayılan bu ülkeler içerisinde boylu ardıç popülasyonlarının oluşturduğu verimli ve bozuk ormanların yüzölçümü bakımından, en büyük olan ülke Türkiye'dir. Boylu ardıç ve diğer ardıç türlerinin yetiştiği topraklar oldukça sert koşullara sahip olabilmektedir. Ardıçların; eğimli, kayalık, taşlık alanlar, dağ yamaçları, besin açısından fakir, kumlu, kireçli topraklarda orman oluşturmasına sıklıkla rastlanır. Ayrıca, ardıçlar su kıtlığına ve şiddetli soğuklara karşı da dirençlidir (OGM, 2014). Boylu ardıç; deniz etkisinden uzak, yıllık ortalama olarak 400-600 mm dolaylarında yağı̧̧ alan alanlarda doğal olarak yetişir. Boylu ardıca 300 ile $2300(-2800) \mathrm{m}$ arasında değişebilen yükseltilerde rastlanır (Coode ve Cullen, 1982). Bu tür, Karadeniz Bölgesi gibi kuzey bölgelerde denizden $300 \mathrm{~m}$ yükseklikteki alanlarda; dahası Karadeniz'in kuzeyindeki Kırım gibi yerlerde neredeyse deniz seviyesi kadar alçak yükseltilerde $(30-40 \mathrm{~m})$ görülür (Douaihy ve ark., 2011). Ancak, güneye doğru gidildikçe boylu ardıca rastlanılan yükselti artar. Boylu ardıç popülasyonları, İç Anadolu ve Akdeniz Bölgeleri’nde $1000 \mathrm{~m}$ ve daha yüksek rakımlı alanlarda görülürken, Lübnan Dağı gibi daha da güney bölgelerde ise $1100 \mathrm{~m}$ ve yukarısında boylu ardıç popülasyonlarına rastlanır (Douaihy ve ark., 2011).

Tüm kara bitkilerinin yetişmesinde toprağın çok önemli bir yeri vardır. Bu nedenle orman varlığının sürdürülebilmesi için en uygun toprak koşullarının bilinmesi ve erozyonla mücadele için ağaçlandırılmak istenen alanların toprak yapısına uyum sağlayabilecek uygun ağaç seçimi için, toprakların fiziksel ve kimyasal yapılarını araştıran çalışmaların ayrı bir önemi bulunmaktadır.

Türkiye'de orman ağaçlarının yetiştiği toprakların fiziksel (bünye) ve kimyasal $(\mathrm{pH}$, elektriksel iletkenlik potasyum, kalsiyum, mangan vb.) yapılarının analizleri yapılarak orman ağaçlarının toprak istekleri ve uyum sağladığı toprak koşullarını inceleyen pek çok araştırma yapıllmıştır (Karaöz, 1991; Özkan, 2004; Altun ve ark. 2007; Gülser ve ark., 2012; Şenol ve ark., 2018).

Önceki yıllarda, Göller Yöresi ve Van-Gevaş’taki boylu ardıç popülasyonlarının yetiştiği toprakların fiziksel ve kimyasal yapısının analizlerine yönelik çalışmalar yapılmıştır (Gülser ve ark., 2012; Şenol ve ark., 
2018). Ancak, yukarıda anılan iki çalışma da boylu ardıçların belli bir bölgedeki (Göller Yöresi ve Van-Gevaş) popülasyonlarına yönelik olmuştur. $\mathrm{Bu}$ nedenle bu türün Türkiye genelindeki popülasyonlarının toprak analizini konu alan bir çalışmaya ihtiyaç olduğu görülmüştür. Böyle bir çalışma ile bu türün yetiştiği toprak koşullarının daha iyi anlaşılması üzerine daha üst düzeyde-genelleyici bir bilgi birikimine sahip olunabilecektir.

Yukarıda yapılan tespitten hareketle bu çalışmanın temel amacı; Türkiye'nin farklı coğrafik bölgelerinden 20 farklı doğal boylu ardıç popülasyonundan alınan toprak örneklerinin bazı fiziksel ve kimyasal özelliklerini belirlemek, karşılaştırmak ve bu türün yetişebildiği edafik (toprakla ilgili) koşullardaki esnekliği ortaya koymaktır.

\section{Çalışma materyali}

\section{Materyal ve Yöntem}

Toprak örneği alınmış boylu ardıç popülasyonların adları (bulunduğu il-ilçe olarak), enlem ile boylam ve yükselti bilgileri Tablo 1'de verilmiştir. Enlem, boylam ve yükselti bilgileri arazide örneklerin alınması esnasında navigasyon (GPS) cihazı kullanılarak elde edilip kaydedilmiştir. Milli park, tohum meşceresi veya gen koruma ormanı gibi özel statülü popülasyonlar parantez içlerinde belirtilmiştir. Enlem-boylam bilgilerine göre popülasyonların dağılımı harita üzerinde gösterilmiştir (Şekil 1).

Örnekleme yapılacak popülasyonların (Tablo 1) belirlenmesinde "Flora of Turkey and the East Aegean Islands" başlıklı eserden ve Orman ve Su İşleri Bakanlı̆̆g'nın kayıtlarından yararlanılmıştır (Coode ve Cullen, 1982; OGM, 2017b). Örnek toplamak amacıyla popülasyonların bulunduğu yerlere gidildiğinde arazinin ortalama eğimi, arazinin kayalık, taşlık vb. olma durumları ve bakıları not edilmiştir. Arazilere ilişkin sözü geçen bu bilgiler Tablo 2'de sunulmuştur.

Tablo1. Çalışmada kullanılan Juniperus taksonlarına ait coğrafik bilgiler

Table 1. Geographical information belong to Juniperus taxa used in the study

\begin{tabular}{|c|c|c|c|c|}
\hline Pop. No & Popülasyon Adı & Enlem & Boylam & Yükselti (m) \\
\hline 1 & Adana-Pozantı & N37º31'55.4" & 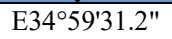 & 1188 \\
\hline 2 & Afyon-Sandiklı & $\mathrm{N} 38^{\circ} 20^{\prime} 25.1^{\prime \prime}$ & $\mathrm{E} 30^{\circ} 07^{\prime} 48.5^{\prime \prime}$ & 1123 \\
\hline 3 & Ankara-Beypazarı (ATM)* & $\mathrm{N} 40^{\circ} 12^{\prime} 48.4^{\prime \prime}$ & $\mathrm{E} 31^{\circ} 40^{\prime} 02.2^{\prime \prime}$ & 535 \\
\hline 4 & Antalya-Elmalı & $\mathrm{N} 36^{\circ} 49^{\prime} 17.7^{\prime \prime}$ & E29०46'03.7" & 1380 \\
\hline 5 & Antalya-Gündoğmuş & $\mathrm{N} 36^{\circ} 51^{\prime} 02.5^{\prime \prime}$ & $\mathrm{E} 32^{\circ} 05^{\prime} 11.0^{\prime \prime}$ & 1405 \\
\hline 6 & Antalya-Termessos (MP)* & N365' $43.5^{\prime \prime}$ & $\mathrm{E} 30^{\circ} 27^{\prime} 31.7^{\prime \prime}$ & 1050 \\
\hline 7 & Aydin-Efeler & N37ㅇ5' $43.9^{\prime \prime}$ & $\mathrm{E} 27^{\circ} 53^{\prime} 51.0^{\prime \prime}$ & 1470 \\
\hline 8 & Burdur-Bucak & $\mathrm{N} 37^{\circ} 24^{\prime} 06.5^{\prime \prime}$ & $\mathrm{E} 30^{\circ} 20^{\prime} 46.0^{\prime \prime}$ & 1360 \\
\hline 9 & Denizli-Acıpayam (GKO)* & N37ํ1'41.6" & E29॰08'02.7" & 1460 \\
\hline 10 & Denizli-Beyağaç (GKO)* & $\mathrm{N} 37^{\circ} 17^{\prime} 52.7^{\prime \prime}$ & E28०58'19.2" & 1180 \\
\hline 11 & Eskişehir-Mihalıççık (GKO)* & $\mathrm{N} 39^{\circ} 50^{\prime} 50.3^{\prime \prime}$ & $\mathrm{E} 31^{\circ} 15^{\prime} 59.7^{\prime \prime}$ & 980 \\
\hline 12 & Eskişehir-Seyitgazi $(\mathrm{GKO}) *$ & $\mathrm{~N} 39^{\circ} 28^{\prime} 53.3^{\prime \prime}$ & E30³9'57.7" & 1010 \\
\hline 13 & Gümüşhane-Torul & $\mathrm{N} 40^{\circ} 32^{\prime} 29.9^{\prime \prime}$ & $\mathrm{E} 39^{\circ} 16^{\prime} 54.8^{\prime \prime}$ & 1112 \\
\hline 14 & Isparta-Senirkent & $\mathrm{N} 38^{\circ} 05^{\prime} 15.0^{\prime \prime}$ & E3048'11.8" & 1369 \\
\hline 15 & Karabük-Eskipazar (ATM)* & $\mathrm{N} 41^{\circ} 00^{\prime} 01.2^{\prime \prime}$ & $\mathrm{E} 32^{\circ} 37^{\prime} 18.5^{\prime \prime}$ & 560 \\
\hline 16 & Konya-Hadim $(\mathrm{GKO})^{*}$ & $\mathrm{~N} 37^{\circ} 02^{\prime} 34.0^{\prime \prime}$ & $\mathrm{E} 32^{\circ} 30^{\prime} 37.2^{\prime \prime}$ & 1440 \\
\hline 17 & Mersin-Mut (GKO)* & 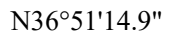 & E331' $46.2^{\prime \prime}$ & 1443 \\
\hline 18 & Mersin-Tarsus (GKO)* & $\mathrm{N} 37^{\circ} 07^{\prime} 00.5^{\prime \prime}$ & $\mathrm{E} 34^{\circ} 27^{\prime} 36.0^{\prime \prime}$ & 1470 \\
\hline 19 & Muğla-Seydikemer (GKO)* & $\mathrm{N} 36^{\circ} 52^{\prime} 41.5^{\prime \prime}$ & E29॰31'03.7" & 1388 \\
\hline 20 & Sinop-Boyabat & $\mathrm{N} 41^{\circ} 37^{\prime} 22.1^{\prime \prime}$ & E343' $18.1^{\prime \prime}$ & 386 \\
\hline
\end{tabular}

* ATM: Ardıç Tohum Meşceresi, GKO: Gen Koruma Ormanı, MP: Milli Park, Pop.: Popülasyon 


\begin{tabular}{|c|c|c|c|c|}
\hline Pop. No & Popülasyon Adı & Arazi & Eğim & Bak1 \\
\hline 1 & Adana-Pozant1 & Toprak & $20^{\circ}$ & Güneydoğu \\
\hline 2 & Afyon-Sandıklı & Taşlık & $30^{\circ}$ & Güney-güneydoğu \\
\hline 3 & Ankara-Beypazarı & Toprak & $40^{\circ}$ & Kuzeybatı \\
\hline 4 & Antalya-Elmalı & Kayalık & $50^{\circ}$ & Kuzeybat1-kuzey-kuzeydoğu \\
\hline 5 & Antalya-Gündoğmuş & Kayalık & $50^{\circ}$ & Kuzey ve güney \\
\hline 6 & Antalya-Termessos & Kayalık & $30^{\circ}$ & Güneydoğu ve kuzeybatı \\
\hline 7 & Aydın-Efeler & Kayalık & $40^{\circ}$ & Güney-güneybatı \\
\hline 8 & Burdur-Bucak & Kayalık & $50^{\circ}$ & Doğu-güneydoğu ve bat1-kuzeybat \\
\hline 9 & Denizli-Acıpayam & Kayalık & $50^{\circ}$ & Kuzey ve güney \\
\hline 10 & Denizli-Beyağaç & Kayalık & $40^{\circ}$ & Doğu-güneydoğu ve bat1-kuzeybat \\
\hline 11 & Eskişehir-Mihalıççık & Taşlık & $10^{\circ}$ & Güney-güneybatı \\
\hline 12 & Eskişehir-Seyitgazi & Taşlık & $20^{\circ}$ & Bat1-güneybatı \\
\hline 13 & Gümüşhane-Torul & Kayalık & $40^{\circ}$ & Güneybat1 ve kuzeydoğu \\
\hline 14 & Isparta-Senirkent & Taşlık & $50^{\circ}$ & Bat1 \\
\hline 15 & Karabük-Eskipazar & Toprak & $30^{\circ}$ & Bat1 \\
\hline 16 & Konya-Hadim & Taşlık & $10^{\circ}$ & Kuzey-kuzeydoğu \\
\hline 17 & Mersin-Mut & Taşlık & $10^{\circ}$ & Kuzey ve güney \\
\hline 18 & Mersin-Tarsus & Toprak & $30^{\circ}$ & Güney-güneybatı \\
\hline 19 & Muğla-Seydikemer & Taşlık & $20^{\circ}$ & Güneybatı ve kuzeydoğu \\
\hline 20 & Sinop-Boyabat & Toprak & $10^{\circ}$ & Güney \\
\hline
\end{tabular}

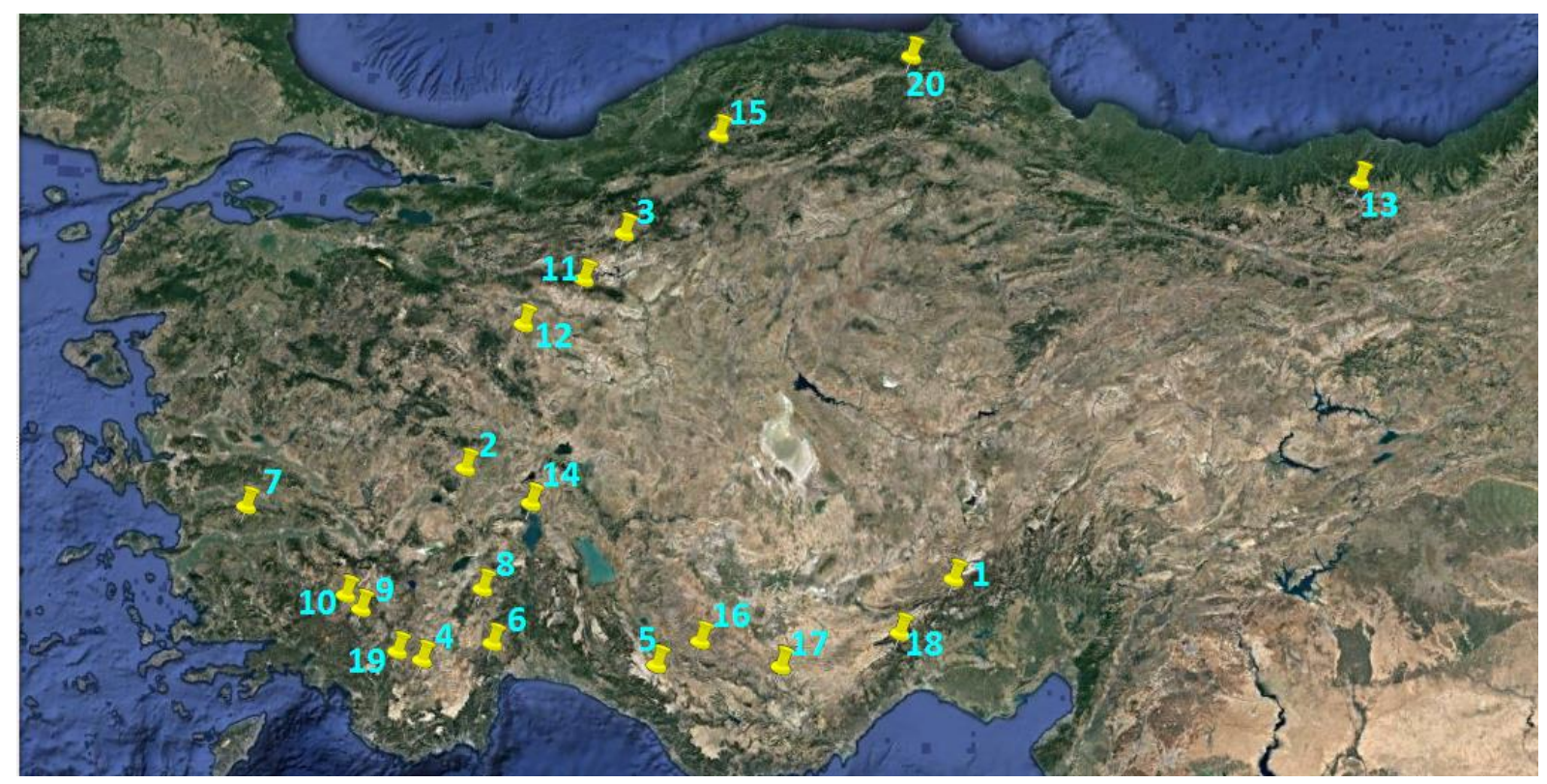

Şekil 1. Bu çalı̧smadaki J. excelsa popülasyonlarının coğrafik yerleşimleri (Tablo 1'deki gibidir)

Figure 1. Geographical locations of J. excelsa populations in this study (As in table 1)

\section{Yönteme İlişkin Bilgiler}

Her popülasyondan, toprak analizleri yapmak amacıyla toprak örnekleri alınmıştır. Toprak örnekleri tercihen şev (yol kenarlarında bulunan; ancak yol seviyesinden yüksekteki toprak sütunlar) kısımlarından alınmıştır. Bu kısımlardan örnek almaktaki amaç, toprağı çok fazla kazmaya gerek kalmadan hem toprağın derin katmanlarından hem de ağaçların köklerinin hizasından $(50-100 \mathrm{~cm})$ örnekleme yapılmasının mümkün olmasıdır. Örnekleme yapılırken keser ile şevin en dış kısımları sıyrılmış ve daha iç kısımdan toprak örnekleri ağaç kökleri hizasından 50-100 cm derinliğe denk gelecek şekilde alınmıştır. Örnekler alınırken büyük taşlar ayıklanmış ve her bir popülasyonun bulunduğu alanın iki farklı yerinden ikişer kilogram toprak örneği alınarak naylon poşetlere konulmuş ve hangi popülasyondan alındığına dair bilgi notu yazılarak poşetlere konulmuştur. 
Kurutma işlemi öncesi aynı popülasyonlardan alınan ikişerli toprak örnekleri birbirine karıştırılarak birleştirilmiştir. Bu şekilde yapılacak ölçümlerin hata payının düşürülmesi hedeflenmiştir.

Topraklar analize gönderilmeden önce taşları ayıklanmıştır. Ardından, toprak kesekleri ahşap çekiç yardımıyla ufalanmıştır ve bu şekilde toprak örnekleri elenebilecek hale getirilmiştir. Ufalanan toprak örnekleri gazete kağıdı üzerine serilmiş ve 2-3 gün boyunca zaman zaman hafifçe karıştırılarak örneklerin nemi uzaklaştırılmıştır. Daha sonra örnekler, gözenekleri $2 \mathrm{~mm}$ çapındaki çelik bir elek ile elenmiştir. Böylece elekten geçirilen kısımlar tekrar poşetlenerek etiketlenmiş, üstte kalan kaba kısımlar ise atılmıştır.

Her bir popülasyondan alınmış toprak örneklerinin “T.C. Gıda Tarım ve Hayvancılık Bakanlığı Batı Akdeniz Tarımsal Araştırma Enstitüsü Müdürlüğü Bölge Toprak Bitki Su ve Gübre Analiz Laboratuvarı” tarafından standart analizi yapılmıştır. Toprak analizinde bakılan başlıca parametreler ve bunların miktarlarının hangi yöntemlere göre belirlendiği aşağıda belirtilmiştir.

Bünye (kil, silt, kum yüzdeleri); hidrometre yöntemi kullanılarak Bouyoucos (1951)'a göre, toprak reaksiyonu $(\mathrm{pH})$ ve elektriksel iletkenlik (EC); 1/2,5 oranında toprak-su karışımında Jackson (1967)'a göre pH metre ve EC metre ile, kireç $\left(\mathrm{CaCO}_{3}\right)$ yüzdesi; Scheibler kalsimetresi ile Çağlar (1949)'a göre, organik madde yüzdesi; modifiye edilmiş Walkey-Black yöntemine (Black, 1965) göre, alınabilir fosfor (P) miktarı; Olsen yöntemine (Olsen ve Sommers, 1982) göre, alınabilir potasyum (K), kalsiyum (Ca) ve magnezyum $(\mathrm{Mg})$ miktarları; $1 \mathrm{~N}$ amonyum asetat ( $\mathrm{pH}=7)$ yöntemine (Kacar, 1962) göre "Atomik Absorbsiyon spektrometresi" kullanılarak ve alınabilir demir $(\mathrm{Fe})$, çinko $(\mathrm{Zn})$, mangan $(\mathrm{Mn})$ ve bakır $(\mathrm{Cu})$ miktarları da DTPA ile ekstraksiyon yolu ile (Lindsay ve Norwell, 1978) "Atomik Absorbsiyon spektrometresi” kullanilarak ölçülmüş̧ür. Bunlara ek olarak, toprak örneklerindeki kil, silt ve kum yüzdelerinin tekstür üçgenindeki (FAO, 1984) kesişimleri belirlenerek toprağın hangi bünye sınıfına (tınlı, kumlu tın, kumlu killi tın vb.) girdiği belirlenmiştir.

Her bir toprak örneğinden elde edilen toprak; $\mathrm{pH}^{\prime}$ ', tuzluluk, kireç, organik madde, fosfor, potasyum, kalsiyum, magnezyum, demir, çinko, mangan ve bakır miktarlarının sınıflandırılması Orman Genel Müdürlüğü’nün “Toprakta Analiz Sonuçlarının Değerlendirilmesinde Kullanılan Sınır Değerler” başlıklı yayını (OGM, 2019) ile Alpaslan ve ark. (2005)'na göre yapılmıștır. Ayrıca, toprakların içerdiği ve ağır metal niteliğindeki çinko ve bakırın üst sınırlarına göre değerlendirilmesinde ise Çevre ve Şehircilik Bakanlığı'nın ilgili mevzuatı (ÇŞB, 2017) esas alınmıştır.

Tüm bunların yanında, toprak örneklerinin yukarıda sözü edilen parametrelere göre istatistiksel analizleri (değişim aralığı, aritmetik ortalama, standart hata, çarpıklık, basıklık ve Pearson korelasyon analizi), IBM-SPSS programı v23 (IBM Corp. Released, 2015) kullanılarak yapılmıştır.

\section{Bulgular ve Tartışma}

\section{Toprakların Analiz Sonuçları ve Sınıflandırılması}

Çalışılan alanlardan toplanmış toprak örneklerinin analizleri sonucunda, örneklerin kil, silt ve kum yüzdeleri ile bünye sınıfları Tablo 3'de özetlenmiştir. 


\begin{tabular}{|c|c|c|c|c|}
\hline Popülasyon & Kil (\%) & Silt $(\%)$ & $\operatorname{Kum}(\%)$ & Bünye Sınıfı \\
\hline Adana-Pozantı & 7,6 & 22 & 70 & Kumlu tın \\
\hline Afyon-Sandiklı & 5,6 & 32 & 62 & Kumlu tin \\
\hline Ankara-Beypazarı & 11 & 20 & 69 & Kumlu tın \\
\hline Antalya-Elmalı & 11 & 18 & 71 & Kumlu tin \\
\hline Antalya-Gündoğmuş & 19 & 32 & 49 & Tin \\
\hline Antalya-Termossos & 11 & 24 & 65 & Kumlu tın \\
\hline Aydin-Efeler & 15 & 50 & 35 & Tin \\
\hline Burdur-Bucak & 13 & 28 & 59 & Kumlu tın \\
\hline Denizli-Acıpayam & 21 & 30 & 49 & Tin \\
\hline Denizli-Beyağaç & 22 & 36 & 42 & Tin \\
\hline Eskişehir-Mihalıççık & 17 & 38 & 45 & Tin \\
\hline Eskişehir-Seyitgazi & 25 & 28 & 47 & Tin \\
\hline Gümüşhane-Torul & 5,6 & 22 & 72 & Kumlu tın \\
\hline Isparta-Senirkent & 21 & 30 & 49 & Tin \\
\hline Karabük-Eskipazar & 12 & 12 & 76 & Kumlu tın \\
\hline Konya-Hadim & 12 & 26 & 62 & Kumlu tın \\
\hline Mersin-Mut & 12 & 24 & 64 & Kumlu tın \\
\hline Mersin-Tarsus & 7,6 & 36 & 56 & Kumlu tın \\
\hline Muğla-Seydikemer & 22 & 22 & 56 & Kumlu killi tın \\
\hline Sinop-Boyabat & 14 & 44 & 42 & Tin \\
\hline En düşük & 5,6 & 12 & 35 & - \\
\hline En yüksek & 25 & 50 & 76 & - \\
\hline Ort. & 14,22 & 28,70 & 57,00 & - \\
\hline
\end{tabular}

Bünye analizlerinde; kil yüzdesi en yüksek olan Eskişehir-Seyitgazi (\%25) ve en düşük olan Gümüşhane-Torul $(\% 5,6)$ ile Afyon-Sandıklı $(\% 5,6)$, silt yüzdesi en yüksek olan Aydın-Efeler $(\% 50)$ ve en düşük olan Karabük-Eskipazar (\%12) ve kum yüzdesi en yüksek olan Karabük-Eskipazar (\%76) ile en düşük olan Aydın-Efeler (\%35)'dir. Toprak bünyesi olarak, Aydın-Efeler ve Sinop-Boyabat hariç geriye kalan tüm toprak örneklerinde kum yüzdesi, silt ve kil yüzdelerinden daha yüksek çıkmışıı. Yalnızca, Aydın-Efeler'de kum yüzdesi 35 iken silt yüzdesi 50 ve Sinop-Boyabat'ta da kum yüzdesi 42 iken silt yüzdesi 44 'dür. Kil yüzdesi ise hiçbir örnekte \%25'i geçmemiştir.

Popülasyonlardan alınan toprak örneklerinin $\mathrm{pH}$, EC (elektriksel iletkenlik), kireç $\left(\mathrm{CaCO}_{3}\right)$, organik madde fosfor $(\mathrm{P})$, potasyum $(\mathrm{K})$, kalsiyum $(\mathrm{Ca})$, magnezyum $(\mathrm{Mg})$, demir $(\mathrm{Fe})$, çinko $(\mathrm{Zn})$, mangan $(\mathrm{Mn})$ ve bakır $(\mathrm{Cu})$ analiz sonuçları Tablo 4'te gösterilmiştir.

Tablo 4'e göre; toprakların $\mathrm{pH}$ değerleri 7,0 ile 8,0 arasında değişmektedir. Bu değer bakımından en yüksek olan popülasyonlar 8,0 ile Eskişehir-Mihalıççık, Gümüşhane-Torul, Mersin-Tarsus ve Sinop-Boyabat, en düşük olan ise 7,0 ile Antalya-Termessos'tur.

Elektriksel iletkenlik (EC) değeri en yüksek olan Karabük-Eskipazar $\left(4,64 \mathrm{mS} \mathrm{cm}^{-1}\right)$, en düşük olan ise Muğla-Seydikemer $\left(0,094 \mathrm{mS} \mathrm{cm}^{-1}\right)$ olmuştur.

Kalsiyum karbonat $\left(\mathrm{CaCO}_{3}\right)$ içeriği en yüksek olanın Mersin-Mut $(\% 60,8)$, en düşük olanın ise Denizli-Acıpayam $(\% 0,5)$ olduğu görülmüştür. ölçülmüştür.

Organik madde yüzdesi en yüksek Denizli-Beyağaç’ta $(\% 10,2)$, en düşük Antalya-Elmalı'da $(\% 0,5)$

Fosfor (P) miktarı en yüksek olanın Antalya-Termessos $\left(76 \mathrm{mg} \mathrm{kg}^{-1}\right)$, en düşük olanların ise AdanaPozantı $\left(6 \mathrm{mg} \mathrm{kg}^{-1}\right)$, Antalya-Elmalı $\left(6 \mathrm{mg} \mathrm{kg}^{-1}\right)$, Denizli-Acıpayam $\left(6 \mathrm{mg} \mathrm{kg}^{-1}\right)$, Mersin-Tarsus $\left(6 \mathrm{mg} \mathrm{kg}^{-1}\right)$ ve Sinop-Boyabat $\left(6 \mathrm{mg} \mathrm{kg}^{-1}\right)$ olduğu görülmüştür.

Potasyum (K) miktarı en yüksek olan Ankara-Beypazarı $\left(567 \mathrm{mg} \mathrm{kg}^{-1}\right)$, en düşük olan ise AydınEfelerdir $\left(12 \mathrm{mg} \mathrm{kg}^{-1}\right)$. 
Kalsiyum (Ca) miktarı en yüksek Karabük-Eskipazar'da (15.594 $\left.\mathrm{mg} \mathrm{kg}^{-1}\right)$, en düşük ise AfyonSandıklı'da (1.326 mg kg-1) ölçülmüştür.

Magnezyum (Mg) miktarı en yüksek olan Isparta-Senirkent (1.039 $\left.\mathrm{mg} \mathrm{kg}^{-1}\right)$, en düşük olan ise AfyonSandıklı (35 $\left.\mathrm{mg} \mathrm{kg}^{-1}\right)$ olmuştur.

Tablo4. Toprak örneklerinin kimyasal analiz sonuçları

Table 4. Chemical analysis results of the soil specimens

\begin{tabular}{|c|c|c|c|c|c|c|c|c|c|c|c|c|}
\hline \multirow[t]{2}{*}{ Popülasyonlar } & \multirow[t]{2}{*}{$\mathrm{pH}$} & \multirow[t]{2}{*}{$\begin{array}{c}\mathrm{EC} \\
\left(\mathrm{mS} \mathrm{cm}^{-1}\right)\end{array}$} & \multirow[t]{2}{*}{$\begin{array}{c}\mathrm{CaCO}_{3} \\
(\%)\end{array}$} & \multirow[t]{2}{*}{$\begin{array}{l}\text { O.mad. } \\
(\%)\end{array}$} & \multicolumn{8}{|c|}{$\left(\mathrm{mg} \mathrm{kg}^{-1}\right)$} \\
\hline & & & & & $\mathbf{P}$ & $\mathbf{K}$ & $\mathbf{C a}$ & Mg & $\mathbf{F e}$ & Zn & Mn & $\mathbf{C u}$ \\
\hline Adana-Pozant1 & 7,9 & 0,196 & 11,7 & 0,8 & 6 & 66 & 7.456 & 1.038 & 9,9 & 0,4 & 6,2 & 2,6 \\
\hline Afyon-Sandıklı & 7,9 & 0,113 & 0,8 & 0,8 & 11 & 64 & 1.326 & 35 & 4,5 & 0,6 & 4,0 & 0,5 \\
\hline Ankara-Beypazarı & 7,5 & 2,2 & 5,5 & 3,0 & 22 & 567 & 4.587 & 556 & 8,7 & 1,5 & 8,9 & 0,5 \\
\hline Antalya-Elmalı & 7,4 & 0,275 & 1,1 & 0,5 & 6 & 116 & 4.931 & 116 & 19,3 & 0,7 & 15,8 & 4,2 \\
\hline Antalya-Gündoğmuş & 7,4 & 0,381 & 8,4 & 3,5 & 19 & 263 & 8.030 & 125 & 27,3 & 1,2 & 14,0 & 1,6 \\
\hline Antalya-Termossos & 7,0 & 0,984 & 30,4 & 9,2 & 76 & 483 & 8.315 & 411 & 27,3 & 5,0 & 15,6 & 1,7 \\
\hline Aydın-Efeler & 7,7 & 0,240 & 9,8 & 1,5 & 7 & 12 & 2.867 & 120 & 4,2 & 0,4 & 15,0 & 0,6 \\
\hline Burdur-Bucak & 7,6 & 0,236 & 19,5 & 1,5 & 7 & 112 & 8.539 & 181 & 13,6 & 0,2 & 13,4 & 1,5 \\
\hline Denizli-Acıpayam & 7,5 & 0,131 & 0,5 & 1,0 & 6 & 70 & 6.409 & 147 & 14,4 & 0,4 & 16,1 & 1,2 \\
\hline Denizli-Beyağaç & 7,3 & 0,489 & 5,8 & 10,2 & 27 & 504 & 7.925 & 200 & 20 & 1,6 & 22,0 & 1,4 \\
\hline Eskişehir-Mihalıççık & 8,0 & 0,168 & 32,6 & 1,5 & 8 & 189 & 4.769 & 409 & 7,5 & 0,2 & 6,1 & 1,3 \\
\hline Eskişehir-Seyitgazi & 7,6 & 0,361 & 9,4 & 2,3 & 9 & 415 & 6.709 & 1.038 & 8,9 & 0,3 & 8,2 & 1,6 \\
\hline Gümüşhane-Torul & 8,0 & 0,162 & 8,6 & 0,8 & 14 & 132 & 4.687 & 309 & 3,4 & 0,6 & 6,9 & 1,2 \\
\hline Isparta-Senirkent & 7,7 & 0,248 & 17,1 & 3,2 & 14 & 263 & 5.052 & 1.039 & 14 & 0,6 & 8,8 & 1,0 \\
\hline Karabük-Eskipazar & 7,2 & 4,64 & 8,6 & 1,9 & 9 & 155 & 15.594 & 259 & 4,8 & 0,2 & 16,6 & 1,0 \\
\hline Konya-Hadim & 7,5 & 0,161 & 0,6 & 2,8 & 7 & 208 & 6.927 & 127 & 6,6 & 0,7 & 12,7 & 1,7 \\
\hline Mersin-Mut & 7,6 & 0,263 & 60,8 & 1,3 & 10 & 64 & 5.270 & 85 & 6,2 & 0,3 & 4,0 & 0,8 \\
\hline Mersin-Tarsus & 8,0 & 0,141 & 55,3 & 1,1 & 6 & 60 & 5.210 & 81 & 5,2 & 0,1 & 3,4 & 0,4 \\
\hline Muğla-Seydikemer & 7,4 & 0,094 & 0,8 & 1,5 & 9 & 230 & 3.522 & 81 & 12,4 & 0,4 & 22,8 & 2,0 \\
\hline Sinop-Boyabat & 8,0 & 0,213 & 16,4 & 2,0 & 6 & 167 & 4.559 & 407 & 9,2 & 0,1 & 4,2 & 1,2 \\
\hline En düşük & 7,0 & 0,094 & 0,5 & 0,5 & 6 & 12 & 1.326 & 35 & 3,4 & 0,1 & 3,4 & 0,4 \\
\hline En yüksek & 8,0 & 4,64 & 60,8 & 10,2 & 76 & 567 & 15.594 & 1.039 & 27,3 & 5 & 22,8 & 4,2 \\
\hline Ort. & 7,61 & 0,58 & 15,18 & 2,52 & 13,95 & 207 & $6.134,2$ & 338,2 & 11,37 & 0,78 & 11,24 & 1,40 \\
\hline
\end{tabular}

Demir (Fe) miktarı en yüksek olanın Antalya-Gündoğmuş (27,3 $\left.\mathrm{mg} \mathrm{kg}^{-1}\right)$ ve Termessos $\left(27,3 \mathrm{mg} \mathrm{kg}^{-}\right.$ $\left.{ }^{1}\right)$, en düşük olanın ise Gümüşhane-Torul $\left(3,4 \mathrm{mg} \mathrm{kg}^{-1}\right)$ olduğu görülmüştür.

Çinko ( $\mathrm{Zn})$ miktarı en yüksek olan Antalya-Termessos $\left(5 \mathrm{mg} \mathrm{kg}^{-1}\right)$, en düşük olanlar ise Mersin-Tarsus $\left(0,1 \mathrm{mg} \mathrm{kg}^{-1}\right)$ ve Sinop-Boyabat'tır $\left(0,1 \mathrm{mg} \mathrm{kg}^{-1}\right)$.

Mangan (Mn) miktarı en yüksek olan Muğla-Seydikemer $\left(22,8 \mathrm{mg} \mathrm{kg}^{-1}\right)$, en düşük olan ise MersinTarsus (3,4 $\left.\mathrm{mg} \mathrm{kg}^{-1}\right)$ olmuştur.

Bakır $(\mathrm{Cu})$ miktarı en yüksek olanın Antalya-Elmalı (4,2 $\left.\mathrm{mg} \mathrm{kg}^{-1}\right)$, en düşük olanın ise Mersin-Tarsus $\left(0,4 \mathrm{mg} \mathrm{kg}^{-1}\right)$ olduğu bulunmuştur

Tablo 5'te toprak örneklerinin $\mathrm{pH}$, tuzluluk, kireç ve organik madde yönünden sınıflandırılmaları OGM (2019)'ye göre yapılmıştır. Buna göre, toprak örneklerindeki ölçülen pH değeri 7,0-8,0 aralığında olup, örnekler pH bakımından nötr $(7)$, hafif alkali $(7,1-7,5)$ ve orta alkali $(7,6-8,3)$ toprak sinıflarına girmektedir.

EC değerlerinin iki örneğin dışındaki tüm toprak örneklerinde çok yüksek olmadığı belirlenmiş olup, bundan hareketle tuzluluk oranlarının da yüksek olmadığı ve bu toprak örneklerinin tuzsuz toprak kategorisine girdiği sonucuna ulaşılmıştır $\left(<2 \mathrm{mS} \mathrm{cm}^{-1}\right)$. Ankara-Beypazarı'ndan alınmış toprak örneğinde EC değeri 2,2 $\mathrm{mS} \mathrm{cm} \mathrm{cm}^{-1}$ ve Karabük-Eskipazar' dan alınmış toprak örneğinde ise bu değer $4,64 \mathrm{mS} \mathrm{cm}^{-1}$ olarak ölçülmüştür. 
Buna göre, Ankara-Beypazarı'nın hafif tuzlu (2-4 $\left.\mathrm{mS} \mathrm{cm}^{-1}\right)$ ve Karabük-Eskipazar'ın da orta derecede tuzlu $\left(4-8 \mathrm{mS} \mathrm{cm}^{-1}\right)$ toprak kategorisine girdiği görülmüştür.

Kireç kapsamları bakımından toprak örnekleri çok değişken bulunmuştur (\%0,5 ile 60,8). Buna göre topraklar kireç içerikleri yönünden özellikleri az kireçliden (<\%1), kireçli (\%1-5), orta kireçli (\%5-15), fazla kireçli (\%15-25) ve çok fazla kireçliye (>\%25) kadar değişkenlik göstermektedir.

Organik madde yüzdesi de topraklarda oldukça değișkenlik göstermiştir (\%0,5-10,2). Çalışılmış olan toprak örneklerinin sınıflandırılması OGM (2019)'de belirtilen toprak kategorilerinden olan kumlu-balçık türündeki topraklar için uygun olacak şekilde yapılmıştır. Dolayısıyla, çalışılan bu topraklar organik madde yönünden düşük $(<\% 0,7)$, orta $(\% 0,7-1,4)$ veya yüksek $(>\% 1,4)$ olarak sinıflandırılmıştır.

Tablo 5. Toprak örneklerinin pH, tuzluluk, kireç ve organik madde yönünden sınıflandırılmaları

Table 5. Classifications of the soil specimens in terms of pH, salinity, lime and organic matter

\begin{tabular}{|c|c|c|c|c|}
\hline \multirow[t]{2}{*}{ Popülasyonlar } & \multicolumn{4}{|c|}{ Toprak Sinıfları } \\
\hline & pH & Tuzluluk & Kireç & Organik madde \\
\hline Adana-Pozant1 & Orta alkali & Tuzsuz & Orta kireçli & Orta \\
\hline Afyon-Sandıklı & Orta alkali & Tuzsuz & Az kireçli & Orta \\
\hline Ankara-Beypazarı & Hafif alkali & Hafif tuzlu & Orta kireçli & Yüksek \\
\hline Antalya-Elmalı & Hafif alkali & Tuzsuz & Kireçli & Düşük \\
\hline Antalya-Gündoğmuş & Hafif alkali & Tuzsuz & Orta kireçli & Yüksek \\
\hline Antalya-Termossos & Nötr & Tuzsuz & Çok fazla kireçli & Yüksek \\
\hline Aydın-Efeler & Orta alkali & Tuzsuz & Orta kireçli & Yüksek \\
\hline Burdur-Bucak & Orta alkali & Tuzsuz & Fazla kireçli & Yüksek \\
\hline Denizli-Acıpayam & Hafif alkali & Tuzsuz & Az kireçli & Orta \\
\hline Denizli-Beyağaç & Hafif alkali & Tuzsuz & Orta kireçli & Yüksek \\
\hline Eskişehir-Mihalıççı1k & Orta alkali & Tuzsuz & Çok fazla kireçli & Yüksek \\
\hline Eskişehir-Seyitgazi & Orta alkali & Tuzsuz & Orta kireçli & Yüksek \\
\hline Gümüşhane-Torul & Orta alkali & Tuzsuz & Orta kireçli & Orta \\
\hline Isparta-Senirkent & Orta alkali & Tuzsuz & Fazla kireçli & Yüksek \\
\hline Karabük-Eskipazar & Hafif alkali & Orta tuzlu & Orta kireçli & Yüksek \\
\hline Konya-Hadim & Hafif alkali & Tuzsuz & Az kireçli & Yüksek \\
\hline Mersin-Mut & Orta alkali & Tuzsuz & Çok fazla kireçli & Orta \\
\hline Mersin-Tarsus & Orta alkali & Tuzsuz & Çok fazla kireçli & Orta \\
\hline Muğla-Seydikemer & Hafif alkali & Tuzsuz & Az kireçli & Yüksek \\
\hline Sinop-Boyabat & Orta alkali & Tuzsuz & Fazla kireçli & Yüksek \\
\hline
\end{tabular}

Toprak örneklerinin içerdikleri potasyum, kalsiyum, magnezyum, demir, çinko, mangan ve bakır gibi makro ve mikro besin elementleri miktarlarının Alpaslan ve ark. (2005)'na göre değerlendirilmesi Tablo 6'da verilmiştir. Ancak toprak içeriklerinin fosfor açısından değerlendirilmesi OGM (2019)'ye göre yapılmıştır.

Tablo 6. Toprak örneklerinin bazı makro ve mikro besin elementlerince değerlendirilmesi

Table 6. Assessment of the soil samples in terms of some macro-micro nutrients

\begin{tabular}{|c|c|c|c|c|c|c|c|c|}
\hline Popülasyonlar & $\bar{P}$ & $\mathrm{~K}$ & $\mathrm{Ca}$ & $\mathrm{Mg}$ & $\mathrm{Fe}$ & $\mathrm{Zn}$ & $\mathrm{Mn}$ & $\mathrm{Cu}$ \\
\hline Adana-Pozant1 & Orta & $\mathrm{Az}$ & Fazla & Fazla & Fazla & $\mathrm{Az}$ & $\mathrm{Az}$ & Yeterli \\
\hline Afyon-Sandıklı & Orta & $\mathrm{Az}$ & Yeterli & Çok az & Orta & $\mathrm{Az}$ & $\mathrm{Az}$ & Yeterli \\
\hline Ankara-Beypazarı & Yüksek & Fazla & Fazla & Fazla & Fazla & Yeterli & $\mathrm{Az}$ & Yeterli \\
\hline Antalya-Elmalı & Orta & $\mathrm{Az}$ & Fazla & $\mathrm{Az}$ & Fazla & Yeterli & Yeterli & Yeterli \\
\hline Antalya-Gündoğmuş & Yüksek & Yeterli & Fazla & $\mathrm{Az}$ & Fazla & Yeterli & Yeterli & Yeterli \\
\hline Antalya-Termossos & Yüksek & Fazla & Fazla & Yeterli & Fazla & Fazla & Yeterli & Yeterli \\
\hline Aydın-Efeler & Orta & Çok az & Yeterli & $\mathrm{Az}$ & Orta & $\mathrm{Az}$ & Yeterli & Yeterli \\
\hline Burdur-Bucak & Orta & $\mathrm{Az}$ & Fazla & Yeterli & Fazla & $\mathrm{Az}$ & $\mathrm{Az}$ & Yeterli \\
\hline Denizli-Acıpayam & Orta & $\mathrm{Az}$ & Fazla & $\mathrm{Az}$ & Fazla & $\mathrm{Az}$ & Yeterli & Yeterli \\
\hline Denizli-Beyağaç & Yüksek & Fazla & Fazla & Yeterli & Fazla & Yeterli & Yeterli & Yeterli \\
\hline Eskișehir-Mihalıççık & Orta & Yeterli & Fazla & Yeterli & Fazla & $\mathrm{Az}$ & $\mathrm{Az}$ & Yeterli \\
\hline Eskişehir-Seyitgazi & Orta & Fazla & Fazla & Fazla & Fazla & $\mathrm{Az}$ & $\mathrm{Az}$ & Yeterli \\
\hline Gümüşhane-Torul & Yüksek & $\mathrm{Az}$ & Fazla & Yeterli & Orta & $\mathrm{Az}$ & $\mathrm{Az}$ & Yeterli \\
\hline Isparta-Senirkent & Yüksek & Yeterli & Fazla & Fazla & Fazla & $\mathrm{Az}$ & $\mathrm{Az}$ & Yeterli \\
\hline Karabük-Eskipazar & Orta & Yeterli & Çok fazla & Yeterli & Fazla & $\mathrm{Az}$ & Yeterli & Yeterli \\
\hline Konya-Hadim & Orta & Yeterli & Fazla & $\mathrm{Az}$ & Fazla & Yeterli & $\mathrm{Az}$ & Yeterli \\
\hline Mersin-Mut & Orta & $\mathrm{Az}$ & Fazla & $\mathrm{Az}$ & Fazla & $\mathrm{Az}$ & $\mathrm{Az}$ & Yeterli \\
\hline Mersin-Tarsus & Orta & $\mathrm{Az}$ & Fazla & $\mathrm{Az}$ & Fazla & Çok az & Çok az & Yeterli \\
\hline Muğla-Seydikemer & Orta & Yeterli & Fazla & $\mathrm{Az}$ & Fazla & $\mathrm{Az}$ & Yeterli & Yeterli \\
\hline
\end{tabular}


$\begin{array}{llllllll}\text { Sinop-Boyabat } & \text { Orta } & \text { Yeterli } & \text { Fazla } & \text { Yeterli } & \text { Fazla } & \text { Çok az } & \text { Az }\end{array}$

Tablo 6' da fosfor miktarlarını sınıflandırmak için düşük, orta veya yüksek; diğer besin elementlerinin miktarları için ise çok az, az, yeterli, fazla veya çok fazla kategorileri kullanılmıştır. Tablo 6'ya göre; topraklardaki fosfor miktarı orta veya yüksek, bakır miktarı yeterli ve kalsiyum ile demir miktarları da ikişer popülasyon dışındaki tüm popülasyonlarda fazladır. Potasyum, magnezyum, çinko ve mangan miktarları ise popülasyonlar arasında oldukça değişkenlik göstermiştir. Örneğin potasyum miktarları; Aydın-Efeler'de çok az, Adana-Pozantı'da az, Isparta-Senirkent'te yeterli ve Denizli-Beyağaç'ta fazla düzeylerde bulunmuştur.

Çinko ve bakır bitkilerin sağlıklı bir şekilde gelişebilmesi için çok az miktarlarda da olsa gereklidir. Ancak, ağır metal sınıfına giren çinko ve bakırın toprakta belli bir miktarın üzerinde bulunması durumunda canlılar için zararlı olmasından ötürü, bunların her zaman belli bir değerin altında olması gerekmektedir (ÇŞB, 2017). Bundan hareketle, çinko ve bakır miktarı toprak örneklerinde belirlenmiş ve bunların derişiminin sırası ile $0,1-5 \mathrm{mg} \mathrm{kg}^{-1}$ ile $0,4-4,2 \mathrm{mg} \mathrm{kg}^{-1}$ arasında değiştiği görülmüştür. Bu da mevzuatta pH değeri 7 ve üzerinde olan kurutulmuş topraklarda çinko $\left(200 \mathrm{mg} \mathrm{kg}^{-1}\right)$ ve bakır $\left(100 \mathrm{mg} \mathrm{kg}^{-1}\right)$ için belirlenmiş olan üst sınırların altındadır (ÇŞB, 2017).

\section{Örneklenen Toprakların İçeriklerinin İstatistiki Değerlendirilmesi}

Tablo 7'de toprakların incelenen parametreler yönünden istatistiksel analiz bulguları verilmiştir. Tüm toprakların ortalamaları göz önüne alındığında toprak bünyelerinin yarıdan fazla oranda kumdan oluştuğu görülmüştür ve toprak asitlik değerlerinin $(\mathrm{pH})$ ortalaması da orta alkali sınıfına $(\mathrm{pH}=7,6-8,3)$ girmektedir. İncelenen toprak örneklerinin ortalama olarak, EC değerlerine göre tuzsuz $\left(\mathrm{EC}<2 \mathrm{mS} \mathrm{cm}{ }^{-1}\right)$, kireç yüzdelerine göre fazla kireçli (\%15-25) ve organik madde miktarının ise yüksek $(>\% 1,4)$ olduğu anlaşılmıştır. Besin elementleri yönünden ise ortalama olarak; fosfor miktarlarının yüksek ( $\left.>12 \mathrm{mg} \mathrm{kg}^{-1}\right)$, potasyum miktarlarının yeterli (140-370 mg kg${ }^{-1}$ ), kalsiyum miktarlarının fazla (3500-10000 $\mathrm{mg} \mathrm{kg}^{-1}$ ), magnezyum miktarlarının yeterli (160-480 mg kg-1), demir miktarlarının fazla $\left(>4,5 \mathrm{mg} \mathrm{kg}^{-1}\right)$, çinko miktarlarının yeterli $\left(0,7-2,4 \mathrm{mg} \mathrm{kg}^{-1}\right)$, mangan miktarlarının az (4-14 mg kg-1) ve bakır miktarlarının ise yeterli $\left(>0,2 \mathrm{mg} \mathrm{kg}^{-1}\right)$ olduğu bulunmuştur.

Tablo 7. Toprakların incelenen özellikler bakımından istatistiksel analiz sonuçları

Table 7. Statistical analysis results of the soils in terms of investigated properties

\begin{tabular}{|c|c|c|c|c|}
\hline & Değişim Aralığı & Ortalama \pm Standart Hata & Çarpıklık & Basıklik \\
\hline Kil (\%) & $19,4(5,6-25)$ & $14,22 \pm 1,302$ & 0,282 & $-0,967$ \\
\hline Silt $(\%)$ & $38(12-50)$ & $28,70 \pm 2,028$ & 0,567 & 0,497 \\
\hline $\operatorname{Kum}(\%)$ & $41(35-76)$ & $57,00 \pm 2,633$ & $-0,131$ & $-1,077$ \\
\hline $\mathrm{pH}$ & $1,0(7,0-8,0)$ & $7,61 \pm 0,065$ & $-0,168$ & $-0,587$ \\
\hline $\mathrm{EC}$ & $4,546(0,094-4,64)$ & $0,58 \pm 0,238$ & 3,389 & 12,045 \\
\hline $\mathrm{CaCO}_{3}(\%)$ & $60,3(0,5-60,8)$ & $15,18 \pm 3,866$ & 1,702 & 2,370 \\
\hline Org. Madde (\%) & $9,7(0,5-10,2)$ & $2,52 \pm 0,583$ & 2,368 & 5,131 \\
\hline $\mathrm{P}\left(\mathrm{mg} \mathrm{kg}^{-1}\right)$ & $70(6-76)$ & $13,95 \pm 3,519$ & 3,566 & 14,000 \\
\hline $\mathrm{K}\left(\mathrm{mg} \mathrm{kg}^{-1}\right)$ & $555(12-567)$ & $207,00 \pm 36,663$ & 1,051 & 0,055 \\
\hline $\mathrm{Ca}\left(\mathrm{mg} \mathrm{kg}^{-1}\right)$ & $14.268(1.326-15.594)$ & $6.134,20 \pm 655,502$ & 1,636 & 5,079 \\
\hline $\operatorname{Mg}\left(\mathrm{mg} \mathrm{kg}^{-1}\right)$ & $1004(35-1.039)$ & $338,20 \pm 74,267$ & 1,450 & 0,946 \\
\hline $\mathrm{Fe}\left(\mathrm{mg} \mathrm{kg}^{-1}\right)$ & $23,9(3,4-27,3)$ & $11,37 \pm 1,618$ & 1,113 & 0,471 \\
\hline $\mathrm{Zn}\left(\mathrm{mg} \mathrm{kg}^{-1}\right)$ & $4,9(0,1-5,0)$ & $0,78 \pm 0,242$ & 3,451 & 13,324 \\
\hline $\operatorname{Mn}\left(\mathrm{mg} \mathrm{kg}^{-1}\right)$ & $19,4(3,4-22,8)$ & $11,24 \pm 1,335$ & 0,369 & $-0,849$ \\
\hline $\mathrm{Cu}\left(\mathrm{mg} \mathrm{kg}^{-1}\right)$ & $3,8(0,4-4,2)$ & $1,40 \pm 0,192$ & 1,911 & 5,347 \\
\hline
\end{tabular}

Tablo 8'de görüldüğü gibi, ölçülen parametrelerin Pearson korelasyon analiz bulguları özetlenmiştir ve $\% 5$ 'lik istatistiksel önem düzeyine göre önemli bulunanlar işaretlenmiştir. Tablo 8 'de 105 adet korelasyona yer verilmiştir. Bunlardan 75 tanesi istatistiksel olarak önem arz etmezken, 30 tanesi istatistiksel olarak önemlidir $(\mathrm{p}<0,05)$. İlk başta $\mathrm{pH}$ ile EC, OM ve besin elementlerinin miktarı arasında (magnezyum dişında) istatistiksel olarak önemli negatif korelasyonlar belirlenmiştir. $\mathrm{Cu}$ ile $\mathrm{pH}$ arasındaki negatif korelasyon ise istatistiksel açıdan önemli bulunmamıştır. OM miktarı ile magnezyum ve bakır dışında kalan besin elementlerinin miktarı arasında ise istatistiksel olarak önemli pozitif korelasyonlar göze çarpmaktadır. Ayrıca, 
OM ile kalsiyum miktarları arasında da istatistiksel olarak önemli olmasa da bir pozitif korelasyon söz konusudur.

Tablo 8. Ölçülen parametrelerin Pearson korelasyon analiz sonuçları

Table 8. Pearson correlations analysis results of parameters measured

\begin{tabular}{|c|c|c|c|c|c|c|c|c|c|c|c|c|c|c|c|}
\hline & Kum & Kil & Silt & $\mathrm{pH}$ & $\mathrm{EC}$ & $\mathrm{CaCO}_{3}$ & $\mathrm{OM}$ & $\mathrm{P}$ & $\mathrm{Mg}$ & $\mathrm{K}$ & $\mathrm{Ca}$ & $\mathrm{Fe}$ & $\mathrm{Mn}$ & $\mathrm{Zn}$ & $\mathrm{Cu}$ \\
\hline Kum & 1,00 & & & & & & & & & & & & & & \\
\hline Kil &,$- 66^{*}$ & 1,00 & & & & & & & & & & & & & \\
\hline Silt &,$- 88^{*}$ &, 23 & 1,00 & & & & & & & & & & & & \\
\hline $\mathrm{pH}$ &,- 19 &,- 32 &, $45^{*}$ & 1,00 & & & & & & & & & & & \\
\hline $\mathrm{EC}$ &, $45^{*}$ &,- 12 &,$- 50^{*}$ &,$- 46^{*}$ & 1,00 & & & & & & & & & & \\
\hline $\mathrm{CaCO}_{3}$ &,- 01 &,- 22 &, 16 &, 24 &,- 11 & 1,00 & & & & & & & & & \\
\hline $\mathrm{OM}$ &,- 20 &, 29 & ,08 &,$- 59^{*}$ &, 12 &,- 002 & 1,00 & & & & & & & & \\
\hline $\mathrm{P}$ &, 12 &,- 04 &,- 13 &,$- 57^{*}$ & 15 &, 12 &, $79^{*}$ & 1,00 & & & & & & & \\
\hline $\mathrm{Mg}$ &,- 02 &, 22 &,- 12 &, 16 & ,04 &,- 05 &, 06 &, 06 & 1,00 & & & & & & \\
\hline $\mathrm{K}$ &,- 05 & ,38 &,- 17 &,$- 51^{*}$ & 25 &,- 17 &, $75^{*}$ & $63^{*}$ &, 34 & 1,00 & & & & & \\
\hline $\mathrm{Ca}$ &, 32 & ,08 &,$- 46^{*}$ &,$- 54^{*}$ &, $71^{*}$ &,- 01 & 29 &, 19 & 10 &, 18 & 1,00 & & & & \\
\hline $\mathrm{Fe}$ &,- 11 & ,36 &,- 08 &,$- 63^{*}$ &,- 11 &,- 13 & $62^{*}$ &, $61^{*}$ & ,001 &, $47^{*}$ &, 23 & 1,00 & & & \\
\hline $\mathrm{Mn}$ &,- 09 &, $49^{*}$ &,- 18 &,$- 77^{*}$ &, 21 &,$- 50^{*}$ & $45^{*}$ &, 25 &,- 29 &, 30 &, 35 &, $52^{*}$ & 1,00 & & \\
\hline $\mathrm{Zn}$ &, 15 &,- 06 &,- 15 &,$- 61^{*}$ & 12 &, 03 &, $77^{*}$ & ,98* &, 03 &, $62^{*}$ &, 15 &, $65^{*}$ &, 30 & 1,00 & \\
\hline $\mathrm{Cu}$ &, 27 &, 06 &,- 39 &,- 27 &,- 18 &,- 32 &,- 03 &,- 01 &, 10 &,- 01 &, 11 &, $46^{*}$ &, 35 &, 09 & 1,00 \\
\hline
\end{tabular}

* \% 5’lik istatistiksel önem düzeyine göre önemli $(P<0,05)$

Bunlar dışında diğer istatistiksel açıdan önemli negatif korelasyonlar; kum-kil, kum-silt, silt-EC, silt$\mathrm{Ca}, \mathrm{CaCO}_{3}-\mathrm{Mn}$ arasındadır. Diğer istatistiksel açıdan önemli pozitif korelasyonlar ise; kum-EC, kil-Mn, siltpH, EC-Ca, P-K, P-Fe, P-Zn, K-Fe, K-Zn, Fe-Mn, Fe-Zn ve Fe-Cu arasındadır.

\section{Bulguların Yorumlanması ve Literatürdeki Benzer Çalışmalarla Karşılaştırılması}

Boylu ardıç popülasyonlarının toprak analiz bulgularının OGM (2019) ve Alpaslan ve ark. (2005)'na göre değerlendirilmesi sonucu; örnekleme yapılan alanlardaki toprağın kalsiyum ile fosfor ve demir miktarları bakımından yeterli olması besin ögeleri açısından fakir olmadığını göstermiştir. Ancak, potasyum, magnezyum, çinko ve mangan miktarlarının yeterli olduğu topraklar yanında, az olduğu topraklar da vardır ki bu durum örnekleme yapılan toprakların arasında bu katyonlar yönünden fakirliğin söz konusu olabildiğini göstermektedir (Tablo 6). A ğır metal miktarının (çinko ve bakır) kabul edilen üst sınırların altında olması ise popülasyonların bu ağır metaller bakımından herhangi bir ekolojik strese maruz kalmadığına işaret etmektedir.

J. excelsa popülasyonlarından alınan toprak örneklerinden elde edilen bulgular, daha ayrıntılı olarak değerlendirildiğinde bu topraklardaki kum ve kireç oranlarının (Afyon-Sandıklı, Denizli-Acıpayam, KonyaHadim ve Muğla-Seydikemer popülasyonları hariç) ortalama bir topraktan yüksek olduğu; dahası MersinTarsus ve Mut örneklerinin de \%55'ten fazla oranda kireç içerdiği görülmektedir. Ayrıca, arazide bu türün yetiştiği toprakların genel olarak taşlık-kayalık nitelikte ve arazi eğimlerinin de ( $\geq \% 30)$ pek çok bölgede fazla olduğu gözlemlenmiştir. Böyle ekolojik koşulların var olduğu topraklarda suyun tutulma miktarı hem oldukça azdır hem de var olan suyun bitkiler tarafından kullanılması güçtür (Taiz ve Zeiger, 2008; Özdemir ve Kahraman 2018; Şişaneci ve Terzi, 2018). Üstelik topraklarda bulunan kum oranının yüksek olması (toprak her ne kadar değişilebilir katyon miktarı bakımından zengin olsa bile) katyon değişim kapasitesinde azaltıcı bir etki yapmaktadır (OGM, 2012). Bütün bunlardan boylu ardıcın kum ile kireç yönünden zengin ve taşlıkkayalık toprak koşullarına ve sarp yamaçlara uyum sağlayarak buralarda ormanlar oluşturabildiği sonucuna ulaşılmaktadır.

Topraktaki organik maddeler, toprakları oluşturan parçacıkları birbirine kenetleyerek toprağa süngerimsi bir yapı kazandırır ve bu yapısı ile topraklar daha iyi su tutar. Bunun yanında, organik maddeler toprağı erozyona karşı koruyucu bir rol de üstlenir (Saltalı, 2015). Organik maddelerin bir diğer işlevi de bitkilerin gelişebilmesi için gerekli olan azot, fosfor ve kükürt gibi önemli besin maddelerini sağlamasıdır. Bu nedenle topraklardaki organik maddelerin çok olması canlı çeşitliliğinin de çok ve toprak verimliliğinin iyi düzeyde olmasını sağlar (Saltalı, 2015). Bu çalışmada da analiz edilmiş topraklarda organik madde miktarı ile besin elementleri arasında istatistiksel olarak önemli pozitif korelasyonun bulunması ( $\mathrm{Ca}, \mathrm{Mg}$ ve $\mathrm{Cu}$ dışında) organik maddelerin mineral madde sağlama özelliğine yorulabilir. Toprakların çoğunlukla organik madde bakımından orta ve zengin nitelikte olduğu görülmüş olsa da; Antalya-Elmalı gibi organik madde açısından 
fakir toprakların da bulunması boylu ardıcın organik madde azlığına karşı toleranslı olabileceğini göstermektedir.

$\mathrm{Bu}$ çalışmada toprak pH'ı ile magnezyum dışındaki incelenen parametreler arasında bulunan istatistiksel olarak önemli negatif korelasyona benzer bulgular başka bazı çalışmalarda da görülmektedir. Örneğin; Khadka ve ark. (2016), Batı Nepal'den alınan toprak örneklerinin analizi sonucunda, toprak asitliği ile topraktaki azot, fosfor ve potasyum miktarları arasında istatistiksel olarak önemli $(\mathrm{p}<0,05)$ negatif korelasyonlar bulmuşlardır. Benzer şekilde Bhat ve ark. (2017), Hindistan'ın Cemmu ve Keşmir Eyaletinde 15 farklı üzüm bağında toprakları analiz etmişler ve yüzey topraklarının $\mathrm{pH}$ '1 ile azot ve fosfor arasında istatistiksel olarak önemli negatif korelasyon belirlemişlerdir. Ayrıca, Bhat ve ark. (2017)'nın bu çalışmasında, pH ile potasyum, kükürt, demir, mangan, çinko, bakır ve bor arasında da negatif korelasyonlar olmasına karşın; bunlar istatistiksel olarak önemli bulunmamıştır.

Toprak pH'ı ile kalsiyum miktarı arasında hem Khadka ve ark. (2016) hem de Bhat ve ark. (2017)'nda istatistiksel olarak önemli pozitif korelasyonlar bulunmuştur. Ancak, bu çalışmada ise toprak pH'ı ile kalsiyum miktarı arasında istatistiksel olarak önemli negatif bir korelasyon söz konusudur. İlgili iki çalışmada analiz edilen toprakların kalsiyum içeriklerinin bu çalışmada ölçülmüş kalsiyum değerlerine göre oldukça düşük olduğu görülmektedir. Kalsiyum değerleri, Khadka ve ark. (2016)' da 20-3.580 mg kg-1 (ort. $884 \mathrm{mg} \mathrm{kg}^{-1}$ ) ve Bhat ve ark. (2017)'de ise 1.819-1.883 mg kg-1 (ort. $1.854 \mathrm{mg} \mathrm{kg}^{-1}$ ) aralıklarında iken bu çalışmada 1.326$15.594 \mathrm{mg} \mathrm{kg}^{-1}$ (ort. $6.134 \mathrm{mg} \mathrm{kg}^{-1}$ ) aralığındadır. Buradan yola çıkılarak, kalsiyum içeriği yüksek olan topraklarda toprak pH'ı ile kalsiyum miktarı arasında negatif korelasyon görülürken; kalsiyum içeriği daha az olan topraklarda tam tersi olarak pozitif korelasyonların göze çarpmakta olduğu çıkarımına varılabilir. Şenol ve ark. (2018) da bu çıkarımı desteklemektedir. İlgili çalışmada toprağın ortalama kalsiyum içerikleri ile toprak pH'1 arasındaki korelasyonlar şu şekildedir: $0-5 \mathrm{~cm}$ derinlikte $\% \mathrm{Ca}=86,75$ iken $\mathrm{r}_{\mathrm{pH}-\mathrm{Ca}}=-0,33(\mathrm{p}<0,05), 5-30$ cm derinlikte $\% \mathrm{Ca}=80,38$ iken $\mathrm{r}_{\mathrm{pH}-\mathrm{Ca}}=0,0,30-60 \mathrm{~cm}$ derinlikte $\% \mathrm{Ca}=77,27$ iken $\mathrm{r}_{\mathrm{pH}-\mathrm{Ca}}=0,37$ ve son olarak 60$120 \mathrm{~cm}$ derinlikte $\% \mathrm{Ca}=65,45$ iken $\mathrm{r}_{\mathrm{pH}-\mathrm{Ca}}=0,88(\mathrm{p}<0,05)$. Topraktaki magnezyum miktarı ise toprak $\mathrm{pH}$ '1 ile hem bu çalışmada hem de yukarıda özetlenen çalışmalarda pozitif korelasyon göstermiştir. Bu korelasyon bu çalışma, Şenol ve ark. (2018) ve Bhat ve ark. (2017)'nda istatistiksel olarak önemli değilken; Khadka ve ark. (2016)'nda önemlidir. Bu yönüyle, bu bulgu her dört çalışma da desteklenmiştir.

Literatürde boylu ardıçların toprak özelliklerinin ele alındığı çalışmalardan Şenol ve ark. (2018)'nda Göller Yöresi (Antalya, Burdur ve Isparta) içerisinde boylu ardıç popülasyonlarının bulunduğu 40 farklı alandan ve her alandaki 0-5, 5-30, 30-60, 60-120 cm'lik derinliklerden örneklenen toprakların bünye, tuzluluk, organik madde ve bazı mineral analizleri $(\mathrm{K}, \mathrm{Ca}, \mathrm{Mg}$ ve $\mathrm{Na}$ ) yapılmıştır. İlgili çalışmada ele alınan toprakların bünyesinde bu çalışmanın bulgularına göre bazı farklılıklar bulunmaktadır. İlgili çalışmada kil yüzdesi ortalamalarının \%26,8-39,5 (en düşük \% 4,7 en yüksek \%60,9) aralığında olduğu bulunmuştur. Ancak, kil yüzdeleri bu çalışmada \%5,6 ile 25 arasında değişmekte olup Şenol ve ark.(2018)'ndaki kil oranlarına göre genel olarak daha düşüktür. Şenol ve ark. (2018)'ndaki toprak bünyelerinin ortalama kum yüzdeleri \%29,932,7 (en düşük \%12, en yüksek \%67) arasında değişmektedir. Bu çalışmada ise, kum oranları \%42-\%76 aralığındadır ve genel olarak Şenol ve ark.(2018) değerlerine göre daha yüksektir. Bunun yanında, Göller Yöresindeki altı boylu ardıç popülasyonun genetik çeşitlilik ve farklılaşmalarının araştırıldığı Yücedağ ve Gailing (2013)'de popülasyonların yetiştiği toprakların üçünün kumlu tın ve diğer üçünün de kumlu kil bünyesine sahip olduğu bildirilmiştir ki bu bulgu boylu ardıç popülasyonlarının yetiştiği toprakların bünyesinde kil oranı kadar kum oranlarının da yüksek olabildiğini göstermektedir. Silt yüzdesi bu çalışma için \%12-50 aralığında iken Şenol ve ark. (2018)'ndaki ortalama silt oranları \%30,7-40,5 (en düşük \%16, en yüksek \%53) arasındadır ve Şenol ve ark. (2018)'nın ortalama silt yüzdeleri de bu çalışmadaki silt yüzdesi ortalamasına göre genel olarak daha yüksektir (Tablo7).

Şenol ve ark. (2018)'nda; ortalama organik madde kapsamları \%2,13-8,88 (en düşük \%0,43 en yüksek \%13,4), ortalama kireç oranları \%8,21-13,02 (en düşük \%0,81, en yüksek \%68,8) ve pH ortalamaları ise 7,66-7,93 (en düşük 5,65, en yüksek 8,58) olarak ölçülmüştür. Bu çalışmada da organik madde ve kireç yüzdesi ile pH Şenol ve ark. (2018) ile önemli ölçüde benzerdir (Tablo 4 ve 5). EC değerlerine göre her iki çalışmada da incelenen toprak örnekleri tuzsuz kategorisinde $\left(<2 \mathrm{mS} \mathrm{cm}^{-1}\right)$ yer almakta ise de bu çalışmada analiz edilen popülasyonlardan ikisinin (Ankara-Beypazarı ve Karabük-Eskipazar) toprağı hafif $\left(2-4 \mathrm{mS} \mathrm{cm}^{-1}\right)$ ve orta tuzlu (4-8 $\left.\mathrm{mS} \mathrm{cm}^{-1}\right)$ sinıflarına girmektedir. 
Van-Gevaş-Altınsaç Köyü'nde bulunan J. excelsa popülasyonunun yedi farklı yerinden ve 0-20, 2040 ve 40-60 cm derinliklerinden alınan toprakların (toplam 21 örnek) bazı fiziksel ve kimyasal özelliklerinin incelendiği Gülser ve ark. (2012)'nda pH değerlerinin 7,8-8,2 arasında olduğu, EC değerlerinin 0,07-0,97 mS $\mathrm{cm}^{-1}$, kireç yüzdesinin oldukça değişken $(\% 0,88-43,56)$, organik madde yüzdesinin 0,17 ile 5,14 arasında değiştiği bulunmuştur. $\mathrm{Bu}$ bulgular, bu çalışmada analiz edilen topraklardaki değerlerle benzerlik göstermektedir (Tablo 4). Bunun yanında, Gülser ve ark. (2012)'nda analiz edilen toprak bünyelerinin tınlı ve killi-tınlı olduğu görülmüştür. Bu çalışmada da ele alınan toprakların bazıları tınlı yapıdadır ve Gülser ve ark. (2012) ile benzerlik göstermektedir. Ancak bu çalışmada toprakların çoğu kumlu tın tanımına uymaktadır (Tablo 3).

Mineral madde bakımından bu çalışmadaki fosfor, potasyum, kalsiyum, magnezyum, demir, çinko, mangan ve bakır miktarları ile Gülser ve ark. (2012) değerleri bir dereceye kadar benzerlik gösterse de bazı önemli farklılıkların olduğu görülmektedir. Örneğin; bu çalışmada topraklar fosfor içerikleri orta veya yüksek düzeyde iken, Gülser ve ark. (2012)'ndaki toprak örneklerinin dördü dışında fosfor içeriklerinin az olduğu (0,91-13 $\left.4 \mathrm{mg} \mathrm{kg}^{-1}\right)$; yani fosfor içeriklerinin $6 \mathrm{mg} \mathrm{kg}^{-1}$ 'den düşük olduğu anlaşılmaktadır. Ayrıca ilgili çalışmada, toprak örneklerindeki potasyum içeriklerinin (55-594 mg kg-1) azdan yükseğe kadar değişen düzeylerde, kalsiyum içeriklerinin (4.443-9.064 mg kg-1) fazla (>3.500 mg kg-1), magnezyum içeriklerinin (712-1.833 mg kg-1) fazla (>480 mg kg-1), demir içeriklerinin $\left(3,98-9,95 \mathrm{mg} \mathrm{kg}^{-1}\right)$ örneklerin biri dişında fazla (>4,5 mg kg-1), çinko içeriklerinin $\left(0,08-1,22 \mathrm{mg} \mathrm{kg}^{-1}\right)$ çok azdan yeterliye kadar değişen düzeylerde, mangan içeriklerinin $\left(5,60-14,09 \mathrm{mg} \mathrm{kg}^{-1}\right)$ örneklerin biri dışında az $\left(<14 \mathrm{mg} \mathrm{kg}^{-1}\right)$ ve bakır içeriklerinin ise $(0,10-1,24$ $\left.\mathrm{mg} \mathrm{kg}^{-1}\right)$ örneklerin biri dışında yeterli $\left(>0,2 \mathrm{mg} \mathrm{kg}^{-1}\right)$ olduğu görülmektedir. Bahsi geçen içerikler yönünden bu çalışma ile Gülser ve ark. (2012) bulgularının önemli ölçüde benzer olduğu söylenebilir. Ancak, farklı olarak bu çalışmadaki topraktaki magnezyum içerikleri belirgin şekilde daha azdır ve bu çalışmada yeterli düzeyde mangan içerikli topraklar da bulunmaktadır.

Bunun yanında; Eyüboğlu ve ark. (1996) da Türkiye topraklarının \%44'ünde çinko ve \%49,8'inde mangan azlığı görüldüğünü bildirmişlerdir (Gülser ve ark., 2012). Bu saptamayı destekler şekilde, bu çalışmada analiz edilen 20 toprak örneğinin 14'ünde çinko ve 12'sinde de mangan azlığı tespit edilmiştir.

İran'ın güneydoğusunda bulunan $J$. excelsa popülasyonlarından seçilmiş dokuz alandaki üçer farklı noktadan ve 0-30 cm derinlikten alınan topraklar, $\mathrm{pH}$, EC, kireç ve bünye gibi parametrelere göre analiz edilmiştir (Zangiabadi ve ark., 2012). Buna göre, seçilmiş bu dokuz alandaki toprakların; pH değerleri 7,498,04, EC değerleri 441-851 $\mu \mathrm{S} \mathrm{cm}^{-1}$, kireç yüzdesi 23-35, kil yüzdesi 9-19, silt yüzdesi 28-36 ve kum yüzdesi ise 50,5-60 arasında değişmiştir (Zangiabadi ve ark., 2012). İlgili çalışmanın bulguları İran'daki J. excelsa popülasyonlarının yayılış gösterdiği toprakların istisnaları olmakla birlikte bu çalışmanın da bulgularına paralel olarak hafif alkalin, düşük tuzlu, yüksek kireçli ve bünye sınıflarının da tınlı ve kumlu-tın olduğu rahatlıkla söylenebilir.

Bu çalışmada ele alınmış olan toprakların fiziksel-kimyasal özellikleri ile ilgili aynı paralellikler Sarangzai ve ark. (2012)'nda da görülmektedir. İlgili çalışmada, Pakistan'ın batı bölümünü oluşturan Belucistan Bölgesi'nde yer alan $J$. excelsa ormanlarının toprakları örneklenerek $(0-25 \mathrm{~cm}$ derinlikten) özellikleri incelenmiştir. Toprak analizinde kullanılan parametrelere göre, topraklardaki organik madde yüzdesinin orta-zengin düzeyde olduğu $(\% 1,1-3,3)$, pH değerlerinin nötr ile orta alkali arasında yer aldığ $(6,9$ $8,0)$, EC'nin toprakların tuzsuz olduğuna işaret ettiği $\left(920-2.760 \mu \mathrm{S} \mathrm{cm}^{-1}\right)$ ve kireç yüzdesinin de 10-15 arasında değiştiğinden hareketle toprakların kalker özelliği gösterdiği bildirilmiştir. Aynı çalışmada topraklardaki ortalama kil, silt, kum ve su tutma kapasitesi yüzdeleri sırasıyla \%5, \%13, \%64 ve \%18 olarak bulunmuş ve çalışılan toprakların ağırlıklı olarak kumlu-tın bünyesine sahip oldukları belirtilmiştir.

\section{Sonuç}

J. excelsa popülasyonlarının büyük çoğunluğu için, çoğu bitkinin kolayca uyum sağlayamayacağ1, tarımsal etkinliklere pek elverişli olmayan ekstrem toprak koşullarına uyum sağlayarak varlığını sürdürdüğü sonucu ortaya çıkmaktadır. Bu yönüyle ekstrem toprak koşullarının bulunduğu bu tür alanlarda, sahip oldukları yaygın kök sistemleriyle, toprağın erozyondan korunması için ardıç popülasyonlarının korunması ve bu tür ekstrem fiziksel-kimyasal özelliklere sahip toprakların erozyondan korunması amacıyla ağaçlandırılması için ardıç türlerinden yararlanılması stratejilerine başvurulmaktadır (Gülcü ve Gültekin, 2005). Bunun yanında, coğrafik konumu belli bir yerde, bir yaşama birliği oluşturan canlılar ile bir yetişme ortamı oluşturan çevre koşulları arasında karşılıklı ve dinamik ilişkilerin bulunduğu çok önemli ekolojik bir birim olarak tanımlanan 
ekosistemin (Çepel, 1995; Kantarcı, 2005) bu tür arazilerde sürekliliğinin sağlanmasında ardıç türlerinin çok büyük bir önemi vardır.

Sonuç olarak; Türkiye'de yayılış gösteren boylu ardıç orman topraklarının bazı fiziksel ve kimyasal özelliklerinin incelenmesini konu alan hem bu çalışma hem de benzer diğer çalışmaların bulguları karşılaştırmalı olarak incelendiğinde, boylu ardıcın fiziksel ve kimyasal yapıları birbirinden oldukça farklı toprak koşullarına uyum sağlayabildiği ve gelişebildiği görülmüştür. Yüksek eğimli, kayalık ve taşlık nitelikteki alanlarda boylu ardıç ormanlarının bulunuşu, derinliği ve su tutma kapasitesi az olan topraklara bu türün uyum sağladığını ve bu yönüyle bu tür alanlarda ekosistemin sürekliliğini sağlamak açısından boylu ardıç türünün öneminin büyük olduğunu göstermektedir. Bu çalışmada analiz edilmiş olan toprak örnekleri içerisinde kireç oranı oldukça fazla, kum oranı yüksek, organik madde, potasyum, magnezyum, çinko veya mangan bakımından yetersiz olanlar bitki büyümesini kısıtlayıcı uç niteliklere sahiptir. Nitekim, Gültekin ve Gültekin (2006)'de “ekstrem toprak (sı̆̆ fizyolojik derinliği az, alkali, besin değeri düşük vb.) ve iklim özelliklerine (güneşli bakılar, kapalı havzalar, şiddetli soğuğa maruz alanlar ve kuru yetişme ortamları) sahip alanlarda yetişebilmek" boylu ardıcın önemli ekolojik özellikleri olarak belirtilmektedir. Bu çalışma ile de Türkiye genelindeki boylu ardıç popülasyonlarının yayılış gösterdiği alanlardaki toprakların ele alınmış fiziksel ve kimyasal özellikler bakımından karakteristikleri ortaya konmuştur. Tüm bunlardan da boylu ardıcın gelişmek için ihtiyaç duyduğu edafik etkenlerin oldukça esnek olduğu sonucuna ulaşılmıştır.

\section{Teşekkür}

Bu çalışmayı "FDK-15-781" nolu proje ile destekleyen “Akdeniz Üniversitesi Bilimsel Araştırma Projeleri Koordinasyon Birimi'ne”, bu makalenin yazarları olarak teşekkürlerimizi sunarız. Bunun yanında; örnekleme yaptığımız il ve ilçelerdeki “Orman İşletme Müdürlükleri ve Şefliklerinde” çalışan ve örnek toplama aşamasında bize yardımcı olan tüm personele teşekkürü bir borç biliriz. 


\section{Kaynakça/References}

Adams, R.P. (2014). Junipers of the World: The Genus Juniperus. Trafford Publishing, USA, 415 p.

Alpaslan, M., Güneş, A. \& İnal, A. (2005). Deneme Tekniği. Ankara Üniversitesi Ziraat Fakültesi Toprak Bölümü Yayını. Ankara, 437s.

Altun, L., Yılmaz, E., Günlü, A., Ercanlı, İ., Usta, A., Yılmaz, M. \& Bakkaloğlu, M. (2007). Murat Dağı (Uşak) yöresinde yayılış gösteren ağaç türlerinin (kızılçam, karaçam ve sarıçam) verimliliğini etkileyen kimi ekolojik etmenlerin araştırılması. Kastamonu Üniversitesi, Orman Fakültesi Dergisi, 7(1): 71-92.

Bhat, Z.A., Padder, S.A., Ganaie, A.Q., Dar, N.A., Rehman, H.U. \& Wani, M.Y. (2017). Correlation of available nutrients with physicochemical properties and nutrient content of grape orchards of Kashmir. Journal of Pharmacognosy and Phytochemistry, 6(2):181-185.

Black, C.A. (1965). Methods of Soil Analysis. Part 2, American Society of Agronomy Inc., Publisher Madison, Wisconsin, U.S.AA. 13721376.

Bouyoucos, G.J. (1951). A recalibration of the hydrometer method form a king mechanical analysis of soil. Agronomy Journal, 43:434-438.

Coode, M.J.E. \& Cullen J. (1982). Juniperus L. In: Davis, P.H. (Ed.). Flora of Turkey and the East Aegean Islands. Edinburg University. Press. pp. 78-84, Edinburg.

Çağlar, K.Ö. (1949). Toprak Bilgisi. Ankara Üniversitesi Ziraat Fakültesi Yayınları. No: 10, Ankara.

Çepel, N. (1995). Orman Ekolojisi. İstanbul Üniversitesi Yayın No: 3886, İstanbul, 536s.

ÇŞB, (2017). Topraktaki Ă̆ır Metal Sınır Değerleri. Çevre ve Şehircilik Bakanlı̆̆ı, Ankara. http://sgb.csb.gov.tr/mevzuat/dosyalar/ r_20131001003814507_7542c1f8-141f-4e9d-bc2f-3c94f17f0c62.pdf. (Erişim tarihi: 05.09.2018).

Douaihy, B., Vendramin, G.G., Boratyński, A., Machon, N. \& Dagher-Kharrat, M.B. (2011). High genetic diversity with moderate differentiation in Juniperus excelsa from Lebanon and the eastern Mediterranean region. AoB Plants, plr003: 1-14.

Eyüboğlu, F., Kurucu, N. \& Talaz, S., (1996). Türkiye topraklarının bitkiye yarayışlı bazı mikro element bakımından genel durumu. Toprak Gübre Araştırma Enstitüsü Genel Yayın No: 217, Seri No: R.133, Ankara.

FAO, (1984). Fertilizer and Plant Nutrition Guide Bulletin. 9. Food and Agriculture Organization. http://www.fao.org/3/a-aq355e.pdf (Erişim tarihi: 05.09.2018).

Fotiadis, G. Angelova, N., Nikolov, N. Melovski, L., Karadelev, M., Avukatov, V. \& Nikolov, L. (2012). Conservation action plan for Grecian juniper forests in the Praspa Lakes Watershed (Final Report). Global Environment Facility-Lawrence Jones Walters, ECNC, Netherlands, $55 \mathrm{p}$.

Gülcü, S. \& Gültekin, C. (2005). Boylu ardıç (Juniperus excelsa Bieb.) ve küçük kozalaklı katran ardıcı'nda (Juniperus oxycedrus L.) uygun ekim yöntemlerinin belirlenmesi. Süleyman Demirel Üniversitesi Orman Fakültesi Dergisi, A(1):37-48, Isparta.

Gülser, F., Çı̆̆ A. \& Türkoğlu, N. (2012). Van'da doğal olarak yetișen ardıç (Juniperus excelsa Bieb.) bitkisinin meyvelerinin besin mineral maddeli içerikleri ile yetişme ortamının toprak özelliklerinin belirlenmesi. Iğdır Üniversitesi Fen Bilimleri Enstitüsü Dergisi, 2(2): 93-98.

Gültekin, H.C. \& Gültekin, Ü.G. (2006). Bazı Türkiye ardıç türlerinin doğal yayılışları, biyolojisi ve ekolojisi. Batı Akdeniz Ormancılık Araştırma Enstitüsü Dergisi, 7(1): 39-66.

Güner, A., Aslan, S., Ekim, T., Vural, M. \& Babaç, M.T. (2012). Türkiye Bitkileri Listesi (Damarlı Bitkiler). Nezahat Gökyiğit Botanik Bahçesi ve Flora Araştırmaları Derneği Yayını, İstanbul, 1290s.

Jackson, M.L. (1967). Soil chemical analysis. Prentice. Hall, Inc., 183:219-284.

Kacar, B. (1962). Plant and Soil Analysis. University of Nebraska College of Agriculture Department. of Agronomy., Lincoln, Nebraska, USA.

Kantarcı, M.D. (2005). Orman Ekosistemleri Bilgisi. İstanbul Üniversitesi Orman Fakültesi Yayınları, İÜ Yayın No: 4594, OF Yayın No: 488, İstanbul Üniversitesi Basım ve Yayınevi, İstanbul, 379s.

Karaöz, M.Ö. (1991). Belgrad Ormanı'nda bazı igne yapraklı ve geniş yapraklı orman ekosistemlerine ait toprak özelliklerinin bir metreküp hacimdeki değerlere göre karşılaştırılması. İstanbul Üniversitesi Orman Fakültesi Dergisi, A-41(1): 60-66.

Khadka, D., Lamichhane, S. \& Thapa, B. (2016). Assessment of relationship between soil pH and macronutrients, Western Nepal. Journal of Chemical, Biological and Physical Sciences, D-6(2): 303-311.

Lindsay, W.L. \& Norwell, W.A. (1978). Development of a DTPA soil test for Zn, Fe, Mn, and Cu. Soil Science Society of America Journal, 42(3):421-428

OGM, (2012). Toprakta Analiz Sonuçlarının Değerlendirilmesi. Orman Genel $\quad$ Müdürlüğü, Ankara .http://ekoloji.OGM.gov.tr/Dokumanlar/Toprak\%20analizi\%20sonu\%C3\%A7lar\%C4\%B1n\%C4\%B1n\%20de\%C4\%9Ferlendiril mesi.pdf (Erişim tarihi: 05.09.2018).

OGM, (2014). Ardıç Ormanlarının Rehabilitasyonu Eylem Planı. Orman Genel Müdürlüğü, Ankara. https://www.ogm.gov.tr/ekutuphane/Yayinlar/Ardıç\%20Ormanlarının\%20Rehabilitasyonu\%20Eylem\%20Planı.pdf. (Erişim tarihi: 05.09.2018). 
OGM, (2017a). Türkiye Orman Varlı̆ğ $2015 . \quad$ Orman $\quad$ Genel Müdürlüğü, https://www.ogm.gov.tr/ekutuphane/Yayinlar/Türkiye\%20Orman\%20Varlığ1-2016-2017.pdf (Erişim tarihi: 05.09.2018).

OGM, (2017b). T.C. Orman ve Su İşleri Bakanlığı Resmi İstatistik Portalı. Orman Genel Müdürlüğü, Ankara. http://rip.ormansu.gov.tr/rip/anasayfa/resimlihaber/17-09-15/Korunan_Alanlar_Ulusal_Sinıflama_Kodları_ aspx?sflang=tr. (Erişim tarihi: 24.01.2019).

OGM, (2019). Toprakta Analiz Sonuçlarının Değerlendirilmesinde Kullanılan Sinır Değerler. Orman Genel Müdürlüğü, Ankara. https://ekoloji.ogm.gov.tr/Dokumanlar/Toprak\%20analiz\%20sonu\%C3\%A7lar\%C4\%B1n\%C4\%B1n\%20de\%C4\%9Ferlendirilmesi.pdf (Erişim tarihi: 30.07.2019).

Olsen, S.R. \& Sommers, L.E. (1982). P Availability Indices. P Soluble in Sodium Bicarbonate, Method of Soil Analysis Part 2. Chem. and Microb. Propert. Edit. A. L. Page, R. H. Miller, D. R. Keeney, 404-430.

Özdemir, A. \& Kahraman, S. (2018). Toprak Bilgisi ve Bitki Besleme. http://www.kitapark.com/pdf/toprak-bilgisi-ve-bitki-besleme.pdf (Erişim tarihi: 05.09.2018).

Özkan, K. (2004). Prof. Dr. Bekir Sıtkı Evcimen Sedir Koruma Ormanı'nda Toros Sediri’nin (Cedrus libani A. Rich) gelişimimi ile yetişme ortamı faktörleri arasındaki ilişkiler. Anadolu Üniversitesi Bilim ve Teknoloji Dergisi, 5(2): 327-332.

Saltalı, K. (2015). Toprak Verimliliğinde Organik Maddenin Önemi. http://www.gubretas.com.tr/tr/icerik/12/1834/toprak-verimliligindeorganik-maddenin-onemi. aspx (Erişim tarihi: 05.09.2018).

Sarangzai, A.M., Ahmed, M., Ahmed, A., Tareen, L. \& Jan, S.U. (2012). Theecology and dynamics of Juniperus excelsa forest in BalochistanPakistan. Pakistan Journal of Botany, 44(5): 1617-1625.

Şenol, Ş., Alaboz, P., Gülsoy, S. \& Özkan, G. (2018). Boylu ardıç (Juniperus excelsa Bieb.) ormanları altındaki toprakların fizikokimyasal özellikleri. Artvin Çoruh Üniversitesi Orman Fakültesi Dergisi, 19(1): 1-10.

Şişaneci, R. \& Terzi, M. (2018). Toprakta pH, Tuzluluk, Kireç ve Bitkiler İçin Önemi. http://slideplayer.biz.tr/slide/1947497/. (Erişim tarihi: 05.09.2018).

Taiz, L. \& Zeiger, E. (2008). Bitki Fizyolojisi. Palme Yayıncılık, 690 s. Ankara.

The World Bank, (2015). Forest Area (\% of Land Area). https://data.worldbank.org/indicator/AG.LND.FRST.ZS (Erişim tarihi: 05.09.2018).

Yücedağ, C. \& Gailing, O. (2013). Genetic variation and differentiation in Juniperus excelsa M. Bieb. populations in Turkey. Trees, 27(3): 547-554.

Zangiabadi, S., Naseri, F. \& Ahmadimoghadam, A. (2012). Investigation on silvicultural properties and soil characteristics of Juniperus excelsa M. Bieb in the south east of Iran. American-Eurasian Journal of Agricultural and Environmental Sci., 12(3): $269-274$. 